\title{
Investigation of Trends in Flooding In the Tug Fork Basin of Kentucky, Virginia, and West Virginia
}

United States

Geological

Survey

Water-Supply

Paper 2203

Prepared in cooperation with the Office of Surface Mining Reclamation and Enforcement and the U.S. Bureau of Mines

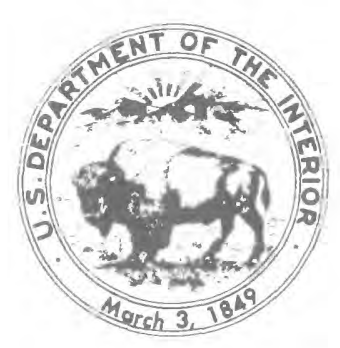




\section{Investigation of Trends in Flooding in the Tug Fork Basin of Kentucky, Virginia, and West Virginia}

\section{By ROBERT M. HIRSCH, ARTHUR G. SCOTT, and TIMOTHY WYANT}

Prepared in cooperation with the

Office of Surface Mining Reclamation and Enforcement

and the U.S. Bureau of Mines 


\title{
UNITED STATES DEPARTMENT OF THE INTERIOR
}

JAMES G. WATT, Secretary

\author{
GEOLOGICAL SURVEY \\ Dallas L. Peck, Director
}

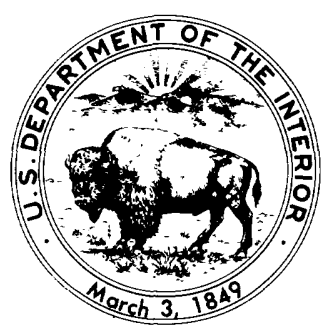

\section{For sale by Distribution Branch}

Text Products Section

U.S. Geological Survey

604 South Pickett Street

Alexandria, Virginia 22304

\section{Library of Congress Catalog in Publication Data}

Hirsch, Robert M.

Investigation of trends in flooding in the Tug Fork Basin of

Kentucky, Virginia, and West Virginia

(U.S. Geological Survey water-supply paper : 2203)

Bibliography: $p$.

Supt. of Docs. no.: । 19.13:2203

1. Tug Fork-Floods. I. Scott, Arthur G. II. Wyant,

Timothy. III. United States. Office of Surface Mining

Reclamation and Enforcement. IV. United States. Bureau

of Mines. V. Title. VI. Series: Geological Survey

water-supply paper ; 2203.

$\begin{array}{lll}\text { GB1399.4.T83H57 52-600082 } & \text { 551.48' 9'097544 }\end{array}$ 


\title{
CONTENTS
}

\author{
Abstract 1 \\ Introduction 1 \\ Basin description 3 \\ Physiography and topography 3 \\ Geology 3 \\ Climate 3 \\ Hydrology 4 \\ Land use and cover 6 \\ Statistical analysis 9 \\ Analysis of annual-flood series 9 \\ Analysis of partial-duration series 12 \\ Multiple-regression methods 14 \\ Changes in stream-channel shape and altitude 20 \\ 03213000 Tug Fork at Litwar, W. Va. 22 \\ 03213500 Panther Creek near Panther, W. Va. 23 \\ 03214000 Tug Fork near Kermit, W. Va. 23 \\ Summary 24 \\ References 28
}

\section{FIGURES}

1. Map showing location of the Tug Fork basin 2

2. Graph showing mean-monthly temperature (1941-70) at Williamson, W. Va. 4

3. Graph showing normal-monthly precipitation (1941-70) at Williamson, W. Va. 4

4. Map showing location of recording-precipitation stations established prior to 1955 in or near the Tug Fork basin 5

5. Map showing location of continuous-record streamflow-gaging stations in the Tug Fork basin 7

6. Hydrograph of mean-monthly discharges (1934-77) at gaging station 03214000 Tug Fork near Kermit, W. Va. 8

7. Photograph of urban and highway utilization of the flood plain along Tug Fork 9

8. Photograph of logged area in the Tug Fork basin 10

9. Photograph of surface-mined area in the Tug Fork basin 11

10. Graph showing annual surface-coal production in the Tug Fork basin 12

11. Graph showing annual-flood series data for Tug Fork at Litwar, W. Va., 1931-79 (03213000) 13

12. Graph showing annual-flood series data for Panther Creek near Panther, W. Va., 1947-79 (03213500) 13

13. Graph showing annual-flood series data for Tug Fork near Kermit, W. Va., 1935-79 (03214000) 13

14. Box plots of annual-flood data for three stream-gaging stations on Tug Fork 14

15. Graph showing expected frequencies of exceedance for different thresholds and time periods for three stream-gaging stations on Tug Fork 15

16. Adjusted variable plot for Tug Fork annual-flood peaks at Litwar, W. Va. 19 
17. Adjusted variable plot for Tug Fork annual-flood peaks near Kermit, W. Va. 20

18. Graphs showing estimated trend in Tug Fork annual-flood peaks at Litwar, W. Va., given 1974-78 meteorological conditions 21

19. Graphs showing estimated trend in Tug Fork annual-flood peaks near Kermit, W. Va., given 1974-78 meteorological conditions 21

20. Rating curve for station 03214000 Tug Fork near Kermit, W. Va. 23

21. Graph showing changes in gage height with time for selected discharges at station 03213000 Tug Fork at Litwar, W. Va. 24

22. Graph showing changes in gage height with time for selected discharges at station 03213500 Panther Creek near Panther, W. Va. 25

23. Graph showing changes in gage height with time for selected discharges at station 03214000 Tug Fork near Kermit, W. Va. 26

24. Graph showing cross sections of stream channel at station 03214000

Tug Fork near Kermit, W. Va. 30

TABLES

1. Recording-precipitation stations established before 1955 in or near the Tug Fork basin 6

2. Continuous-record steamflow-gaging stations in the Tug Fork basin 6

3. Suspended-sediment stations in the Tug Fork basin 8

4. Land use in the Tug Fork basin for 1973-76 8

5. Annual surface-coal production in the Tug Fork basin 12

6. Statistics of annual-flood series 14

7. Trends in the maximum 2-day rainfall associated with the annual flood 15

8. Test statistics for expected frequencies of exceedance 16

9. Tug Fork near Litwar-regression analysis of relative trends in annual-flood peaks 17

10. Tug Fork near Kermit-regression analysis of relative trends in annual-flood peaks 18

11. Additional relative trend results for Litwar and Kermit based on robust regression 19

12. Tug Fork at Litwar-regression analysis of trends in annual-flood peaks related to different coal production indexes 22

13. Tug Fork near Kermit-regression analysis of trends in annual-flood peak related to different coal production indexes 22

14. Gage height for selected discharges at gaging station 03213000 Tug Fork at Litwar, W. Va. 27

15. Gage height for selected discharges at gaging station 03213500 Panther Creek near Panther, W. Va. 28

16. Gage height for selected discharges at gaging station 03214000 Tug Fork near Kermit, W. Va. 29

\section{APPENDIXES}

A. Data set for Tug Fork at Litwar, W. Va. 33

B. Augmented data set for Tug Fork at Litwar, W. Va. 34

C. Data set for Tug Fork near Kermit, W. Va. 35

D. Augmented data set for Tug Fork near Kermit, W. Va. 36

E. Data set for Panther Creek near Panther, W. Va. 37 


\title{
Investigation of Trends in Flooding in The Tug Fork Basin of Kentucky, Virginia, And West Virginia
}

\author{
By Robert M. Hirsch, Arthur G. Scott, and Timothy Wyant
}

\begin{abstract}
Statistical analysis indicates that the average size of annual-flood peaks of the Tug Fork (Ky., Va., and W. Va.) has been increasing. However, additional statistical analysis does not indicate that the flood levels that were exceeded typically once or twice a year in the period 1947-79 are any more likely to be exceeded now than in 1947. Possible trends in streamchannel size also are investigated at three locations. No discernible trends in channel size are noted. Further statistical analysis of the trend in the size of annual-flood peaks shows that much of the annual variation is related to local rainfall and to the "natural" hydrologic response in a relatively undisturbed subbasin. However, some statistical indication of trend persists after accounting for these natural factors, though it is of borderline statistical significance. Further study in the basin may relate flood magnitudes to both rainfall and to land use.
\end{abstract}

\section{INTRODUCTION}

The Tug Fork basin encompasses about 1,560 square miles of the mountainous area of Kentucky, Virginia, and West Virginia (fig. 1). The river serves as the political boundary between Kentucky on the west and West Virginia on the east. It joins the Levisa Fork at Louisa, Ky., to become the Big Sandy River. The Big Sandy River flows northward to join the Ohio River at Catlettsburg, Ky. Mining of the area's extensive coal deposits is the primary industry in the basin.

Flooding has long been a major problem in the basin. Most of the inhabitable land lies on the narrow flood plains between steep mountains. Both the Tug Fork and the Big Sandy River basins have a long history of devastating floods. Carol Crowe-Carraco (1979), referring to a Civil War experience of 1862 in the Big Sandy River basin, states,
Orlando Bowles, a young lieutenant of the Fortieth Ohio and later a prominent Big Sandian, could not have enjoyed the Middle Creek campaign and his first days in the Big Sandy. It was raining and had been for several weeks. The ground was soaked, and mud covered the infantrymen from head to toe as they slogged along. The Big Sandy River, swollen by rain and melting snow, had risen sixty feet from its lowest watermark and was flooding. Yellow torrents of water seemed to be everywhere. Paintsville was under water; Piketon [sic] had steamboats on Main Street; and at Camp Buell, Bowles's tent and equipment were swept away by the raging river. The record flood of January-February 1862 played havoc with the countryside, and supplies from downriver were cut off.

She further states (1979), in reference to 1927 ,

In the midst of reduced production and wage cuts came the most devastating flood the region had suffered in years. During the night of May 30, 1927, rain fell for twelve hours, and the Big Sandy River and its tributaries flooded their banks with unprecedented vehemence. A wall of water thirty feet high inundated the valley's log cabins and frame dwellings, and close to a hundred people died. Automobiles vanished, and livestock drowned.

From April 4 to 5, 1977, an extremely devastating flood occurred in the Big Sandy River basin. Economic damage approached $\$ 50$ million in the Tug Fork valley alone (Runner, 1979; Runner and Chin, 1980). This flood prompted much speculation as to what affect various land uses, particularly surface mining, have on the flood and sediment discharge characteristics of Appalachian rivers. No large-scale investigation has been conducted to definitively answer this question.

The U.S. Geological Survey, in cooperation with the U.S. Bureau of Mines and the Office of Surface Mining Reclamation and Enforcement, began a study in early 1980 of flooding in the Tug Fork basin (Scott, 1980). The objectives of the study are (1) to identify relative effects of the various land-use changes on the flood hydrology, (2) to assess the effectiveness of present mine-reclamation practices for controlling 

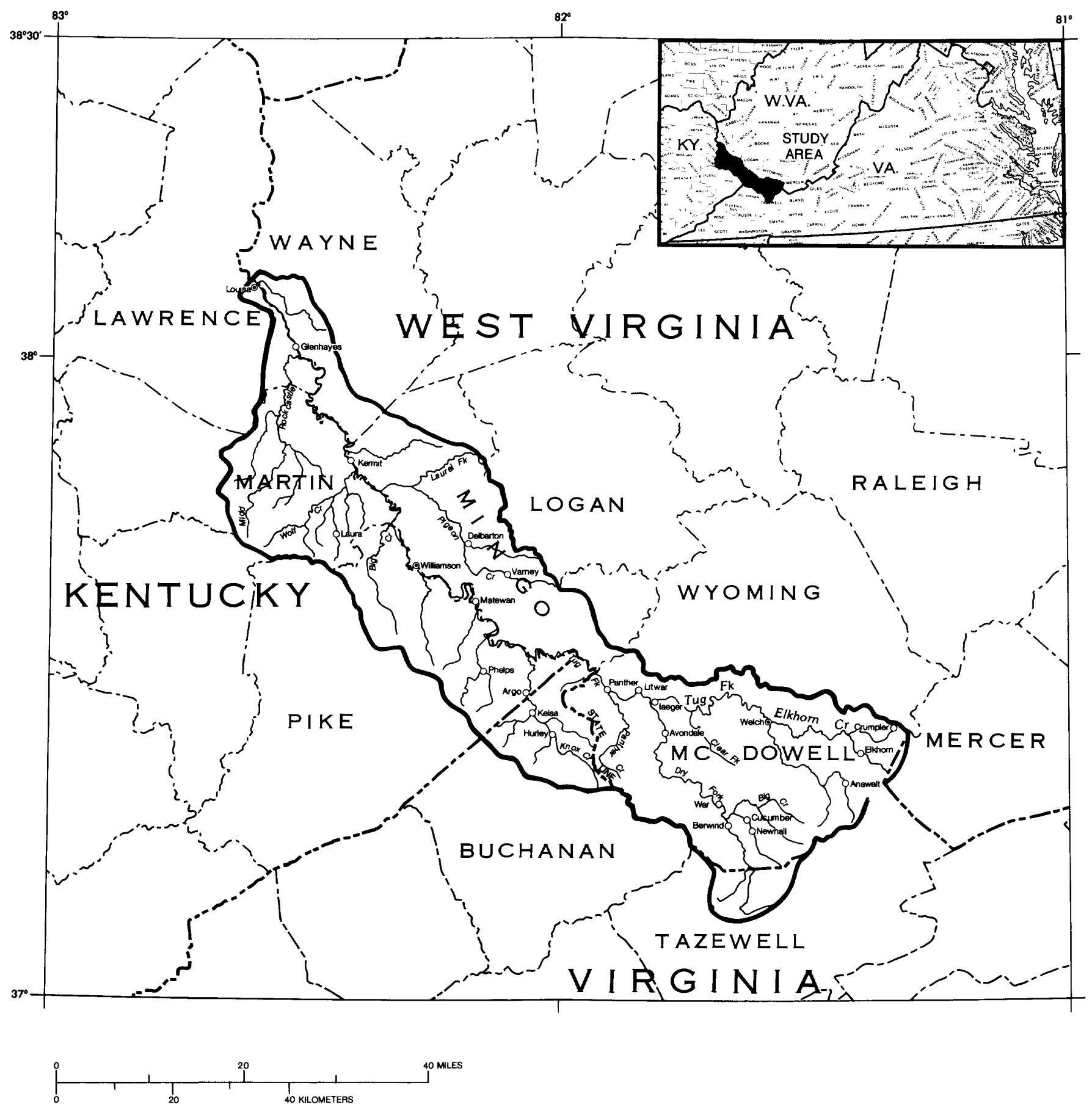

Figure 1. Location of the Tug Fork basin.

undesirable aspects of storm runoff, and (3) to observe and analyze cumulative impacts of typical land-use changes on sediment and flood characteristics at downstream points in the Tug Fork basin.

This report documents methodology and results of statistical analyses performed to determine whether changes or trends in flooding characteristics of the basin can be identified from historical data. The evaluation of trends or changes in flooding characteristics will be considered in four parts. The first is the univariate statistical analysis of annual-flood-series data from the three long-term stream gages. The second is the univariate 
statistical analysis of the partial-duration-series data at these same stations. The third part is a multipleregression analysis of annual-flood discharges at two gages downstream of substantial amounts of surfacemined land. This third analysis explores the extent to which any trends found in the analysis of part one can be related to rainfall, flood discharges in a relatively unmined area, and coal production indexes. The fourth part explores the possibility that channel-geometry changes have occurred, which affect the stage-discharge relation.

\section{BASIN DESCRIPTION}

\section{Physiography and Topography}

The Tug Fork basin encompasses nearly 1,560 square miles of Kentucky, Virginia, and West Virginia. Some of the principal tributaries to the Tug Fork are Pigeon Creek, Panther Creek, Elkhorn Creek, and Dry Fork in West Virginia; Knox Creek in Virginia; and Rockcastle Creek in Kentucky. About 60 percent of the basin is in West Virginia, 30 percent in Kentucky, and 10 percent in Virginia. Nearly the entire basin is in the Kanawha section of the Appalachian Plateau physiographic province as defined in Fenneman (1946).

The topography of the basin is characterized by narrow river valleys bordered by steeply rising mountains. Mountains rise as much as 1,300 feet above the valley floor. Maximum elevation of about 3,400 feet occurs in the headwaters, and the minimum elevation of about 530 feet occurs at the mouth.

\section{Geology}

The following general description of the geology of the Tug Fork basin is taken from a report by the U.S. Army Corps of Engineers (1979) except for the stratigraphic names, which have been capitalized to conform with Geological Survey usage.

The Tug Fork basin lies on the southwestern fringes of the deepest portion of the Appalachian sedimentary basin. The northern portion of the study area displays the classical concentric outcrop pattern of horizontal strata in which the younger Pennsylvanian bedrock (Conemaugh Group) is found in the uplands while the older Pennsylvanian bedrock (Kanawha Formation) is exposed in the stream valleys. The Conemaugh Group is composed primarily of a cyclic sequence of shale, siltstone, and sandstone, with thin limestone and coal beds. Underlying the Conemaugh in the north is the Allegheny Formation, consisting of cyclic sequences of sandstone, siltstone, shale, limestone, and coal. The underlying [equivalent of the]
Pottsville Group, composed of the Kanawha Formation, the New River Formation, and the Pocahontas Formation, is the most prevalent exposed bedrock in the Tug Fork basin. The group is composed of over 50 percent sandstone with some shale, siltstone, and coal. It is in this group of sedimentary rock that most of the coal resources of the area can be found. All of the bedrock in the study area, with one minor exception, is Pennsylvanian in age.

The outcrop pattern shows that the strata in the southern portion of the Tug Fork basin dip to the northwest, so that progressively older formations are exposed in the south. The surface drainage system also exposes these older beds in the stream valleys. The extreme southeastern portion of the basin contains the only Mississippian outcropping sandstone in the study area, along the axis of the Dry Fork Anticline.

A series of extremely gently sloping anticlines and synclines, trending approximately east-west, cross [sic] the basin in the north. The Warfield fault, also cutting across the northern part of the study area, is a normal fault in the Pennsylvanian bedrock, with the upthrown side to the south. There is about 200 feet of vertical displacement along this fault, and the surface topography remains relatively undisturbed over it.

The Quaternary deposits consist of recent river alluvium (sands and gravels) deposited on the floodplain floor of the Tug Fork and along the banks of its major tributaries. The source material for the majority of these deposits comes from the upland slopes at the head waters and along the banks of the rivers. Soil cover on these slopes tends to be relatively thin because the steep slopes allow the soils to be washed into the river during periods of even moderate rainfall. The river can carry a large load of sediment during times of high flow or flooding (usually the spring). It deposits the sediments on its banks and at different points in the channel as its load-carrying capacity and energy are reduced during periods of low flow. Floodplain deposition occurs when flood waters recede and suspended material is laid down on the floodplain. Channel deposition occurs when physical constraints cause the river water velocity to be reduced, thus decreasing its carrying capacity. The deposits may occur as point bars along the inside of sharp bends, while the outside of the bend is simultaneously being scoured. Deposition also may occur as delta bars, formed by tributary streams building deltas into the channel of the main stream. Deposits, ranging in size from silts to boulders, are commonly found in the channel and have been carried considerable distances downstream during floods and high water.

\section{Climate}

The climate of the area is characterized by a moderately severe winter with frequent alternations of fair and stormy weather and hot, showery summers. Mean-annual precipitation is about 44 inches. The 
mean-minimum-January temperature is about $28^{\circ} \mathrm{F}$ and mean-maximum-July temperature is about $88^{\circ} \mathrm{F}$. The basin is in an area of prevailing westerly winds that, during the colder portions of the year, are interrupted by northward surges of warm air and southward surges of cold air associated with the passage of high- and lowpressure cells. The low-pressure areas are the largedimension storms known as extratropical cyclones. Because of these fluctuations, most snowstorms are followed by thawing periods, and no wide-scale springmelt of an accumulated snowpack takes place. Snowfall varies greatly within the area, but the area west of longitude $81^{\circ} 30^{\prime}$ receives about 15 inches per year (Horn and McGuire, 1960; Anderson, 1969; Crockett, 1971).

The mean-monthly temperatures and normalmonthly precipitation for Williamson, West Va. (1941-70), shown in figures 2 and 3, are typical of much of the basin (National Oceanic and Atmospheric Administration, 1973).

Intense rainfall is a common source of flooding in the basin. An extreme storm occurred in April 1977. Maximum observed rainfall was 15.5 inches in about 30 hours at Jolo, W. Va.; this rainfall is more than twice the amount expected for a 100-year recurrence-interval storm (Runner and Chin, 1980).

Table 1 shows the name, number, location, and period of record for National Weather Service (NWS) recording-precipitation stations established before 1955 in and near the Tug Fork basin. The location of these sites is shown in figure 4 .

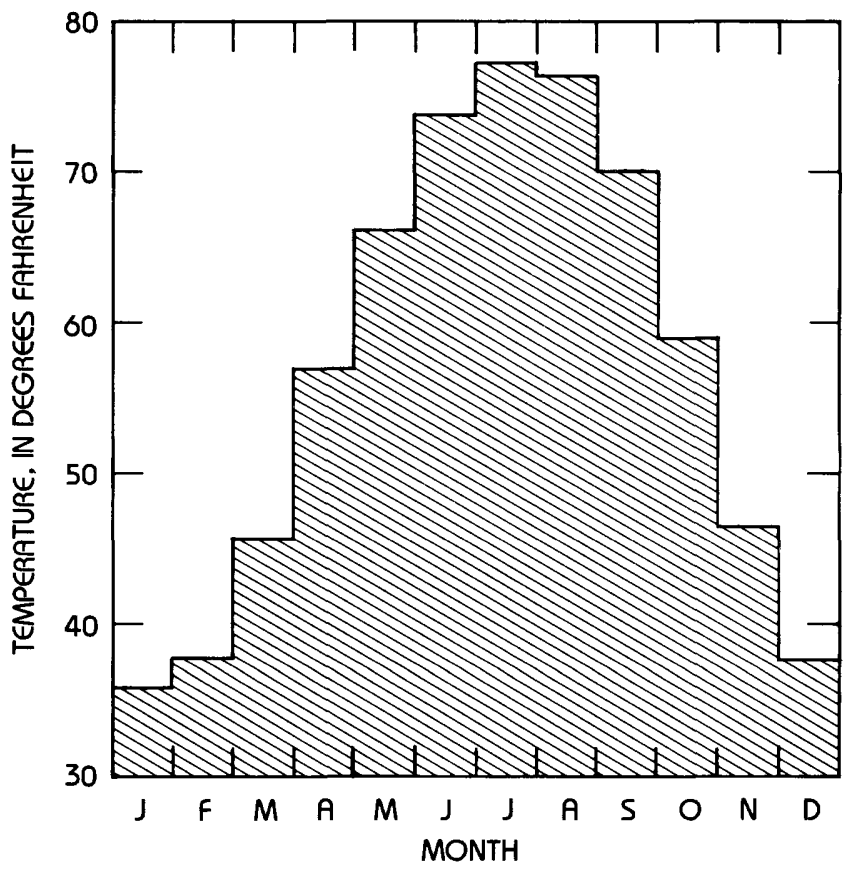

Figure 2. Mean-monthly temperature (1941-70) at Williamson, W. Va. (National Oceanic and Atmospheric Administration, 1973).

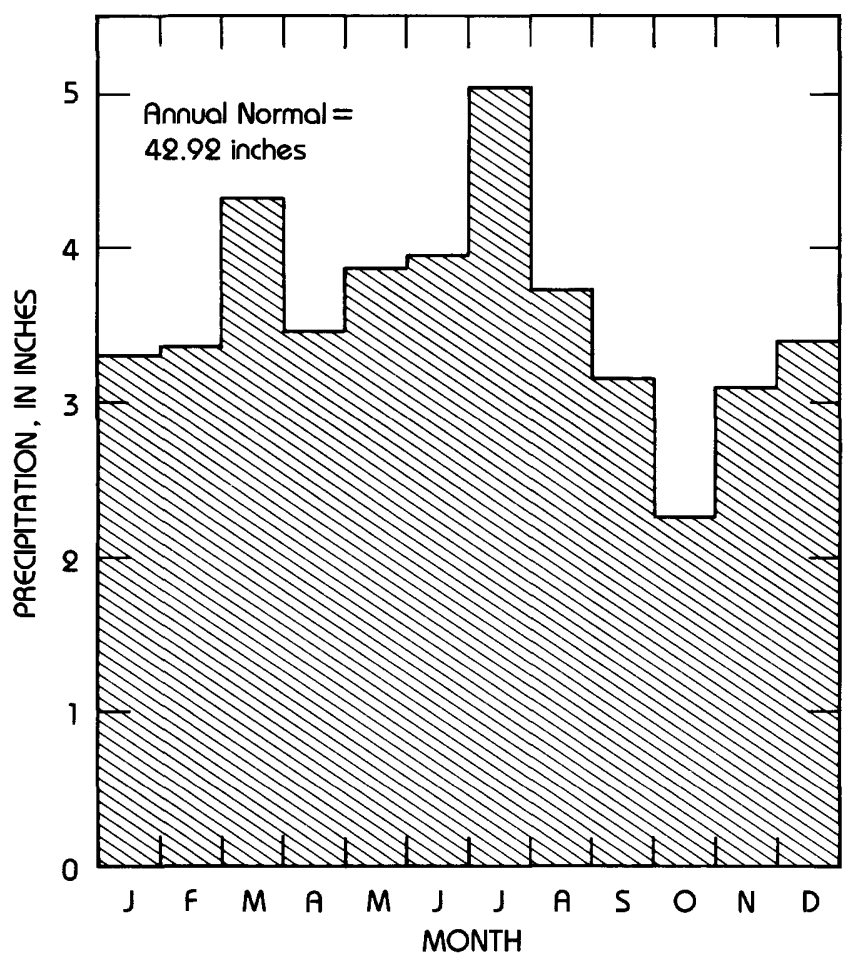

Figure 3. Normal-monthly precipitation (1941-70) at Williamson, W. Va. (National Oceanic and Atmospheric Administration, 1973).

\section{Hydrology}

Tug Fork flows northwest for about 150 miles from its headwaters on the West Virginia-Virginia border to its confluence with the Levisa Fork at Lousia, Ky. The river generally winds through a narrow, steeply sided valley. River depth at base (low) flow varies from a few inches in the headwater tributaries to about 10 feet at Glenhayes, W. Va. Width of the main channel ranges from 50 feet or less in the headwaters to over 250 feet in the downstream reaches. Because of the steep slopes, much of the development in the basin is along the narrow flood plains. The width of these flood plains varies from a few hundred feet in the upstream reaches to about 1,800 feet at Williamson, W. Va.

The Geological Survey operates 11 gaging stations that provide continuous records of streamflows in the basin. The locations of these sites are shown in figure 5 . Station number, name, drainage area, and period of record are listed in table 2 .

Runoff in the basin is generally highest during February and March and lowest during September and October. A typical distribution of streamflow is illustrated in figure 6, a hydrograph of the mean of monthly discharges for 1934 through 1979 at station 03214000 Tug Fork near Kermit, W. Va. 


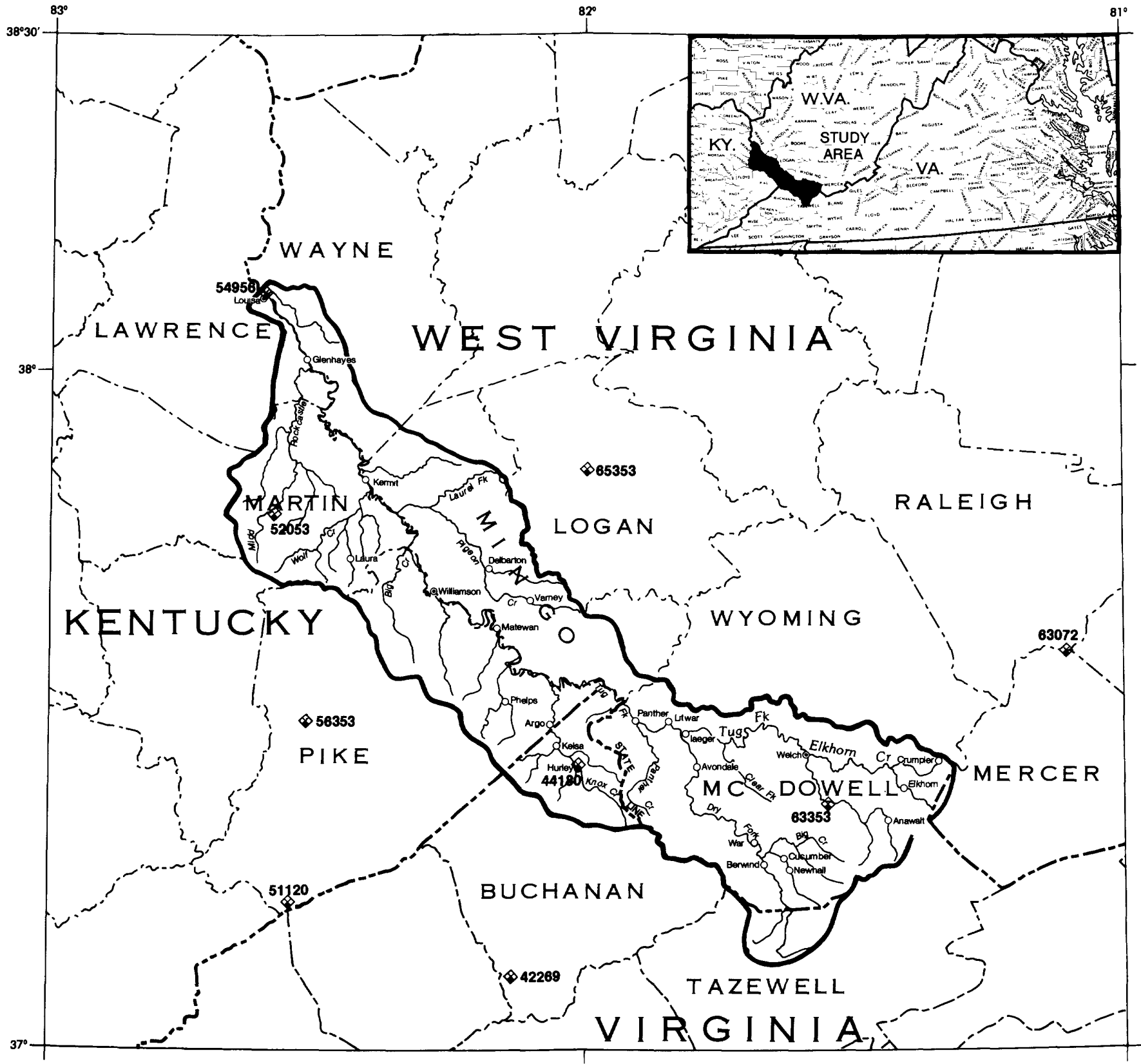

44180- Precipitation station, National Weather Service number.

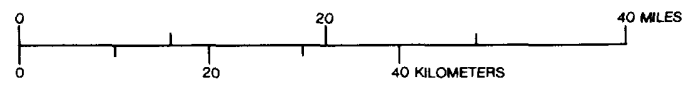

Figure 4. Location of recording-precipitation stations established before 1955 in or near the Tug Fork basin.

The maximum observed discharge in the basin was $104,000 \mathrm{ft}^{3} / \mathrm{s}$. This flow occurred during April 1977 at station 03214000 Tug Fork at Kermit, W. Va. The recurrence interval of this discharge at this site is more than 100 years (Runner and Chin 1980). Other major floods in the basin occurred during 1875, 1918, 1955, 1957, 1963, and 1967.

Systematic collection of suspended-sediment and other water-quality data in the basin began only recent- ly. Suspended-sediment data are currently (1980) being collected continuously by the Geological Survey at the stations listed in table 3.

All of these data are published annually in the Geological Survey annual series of reports on water resources data for each State (U.S. Geological Survey, annual series, 1961-present). 
Table 1. Recording-precipitation stations established before 1955 in or near the Tug Fork basin

\begin{tabular}{|c|c|c|c|c|}
\hline \multirow{2}{*}{ Name } & \multirow{2}{*}{$\begin{array}{l}\text { NWS } \\
\text { Number }\end{array}$} & \multicolumn{2}{|c|}{ Location } & \multirow{2}{*}{ Period of record } \\
\hline & & Latitude & Longitude & \\
\hline \multicolumn{5}{|c|}{ TUG FORK BASIN } \\
\hline Davella, Ky.-- & 52053 & $37^{\circ} 48^{\prime}$ & $82^{\circ} 35^{\prime}$ & 1940-present \\
\hline Hurley, Va. -- & 44180 & $37^{\circ} 25^{\prime}$ & $82^{\circ} 01^{\prime}$ & 1941-present \\
\hline Gary, W. Va.-- & 63353 & $37^{\circ} 22^{\prime}$ & $81^{\circ} 33^{\prime}$ & 1941-present \\
\hline \multicolumn{5}{|c|}{ ADJACENT } \\
\hline Burdine 2 NE, Ky. - & 51120 & $37^{\circ} 13^{\prime}$ & $82^{\circ} 35^{\prime}$ & 1951-present \\
\hline Louisa 2 NE, Ky.------- & 54946 & $38^{\circ} 07^{\prime}$ & $82^{\circ} 38^{\prime}$ & 1941-present \\
\hline Pikeville 2, Ky. - - & 56353 & $37^{\circ} 29^{\prime}$ & $82^{\circ} 32^{\prime}$ & 1934-present \\
\hline Davenport $2 \mathrm{NE}$, Va. ---- & 42269 & $37^{\circ} 07^{\prime}$ & $82^{\circ} 06^{\prime}$ & 1940-present \\
\hline Flat Top, W. Va.-- & 63072 & $37^{\circ} 35^{\prime}$ & $81^{\circ} 06^{\prime}$ & 1940-present \\
\hline Logan, W. Va.-- & 65353 & $37^{\circ} 51^{\prime}$ & $82^{\circ} 00^{\prime}$ & 1941-present \\
\hline
\end{tabular}

\section{Land Use and Cover}

The Tug Fork basin is predominantly rural. The cities of Williamson, W. Va., with a population of about 5,500, and Welch, W. Va., with a population of about 4,600 (U.S. Geological Survey, 1970), are the major areas of urbanization. The remaining population is scattered among the small towns and single-family dwellings located throughout the river valleys.

Historically, land use in the basin has changed from small individual homesteads and gardens to the extensive surface mining of today. Coal mining has been widespread in the basin since the late 1800 's. Prior to World War II, mining was conducted mostly by underground methods. Since that time, the use of surfacemining techniques has accelerated greatly. The use of surface mining probably has increased because of the improvement in stripping machinery and the growing energy-related demands for coal.

From 1880 to 1910 , logging was an important industry in the basin. Hundreds of log rafts were reported to have been floated along the Tug and Levisa Forks in May 1903, and, by May 11, 1903, over 1,000 rafts docked at Catlettsburg (Crowe-Carraco, 1979).

Vegetation in the basin consists primarily of deciduous hardwoods with some scattered conifers.

Figures 7,8 , and 9 are photographs showing various types of land use in the basin. Figure 7 shows urban and highway utilization of a flood plain, figure 8 shows logging, and figure 9 shows surface mining.

Recent land-use mapping (U.S. Geological Survey, 1976, 1978a, b) identified the following land use and cover categories within the basin:

- Urban or built-up-Residential, commercial and services, industrial, and mixed urban or built-up land,

- Agricultural-cropland and pasture,

- Forest-deciduous forest and mixed forest,

- Water-reservoirs, and

- Barren-strip mines, quarries, and gravel pits and transitional areas.

Table 2. Continuous-record streamflow-gaging stations in the Tug Fork basin

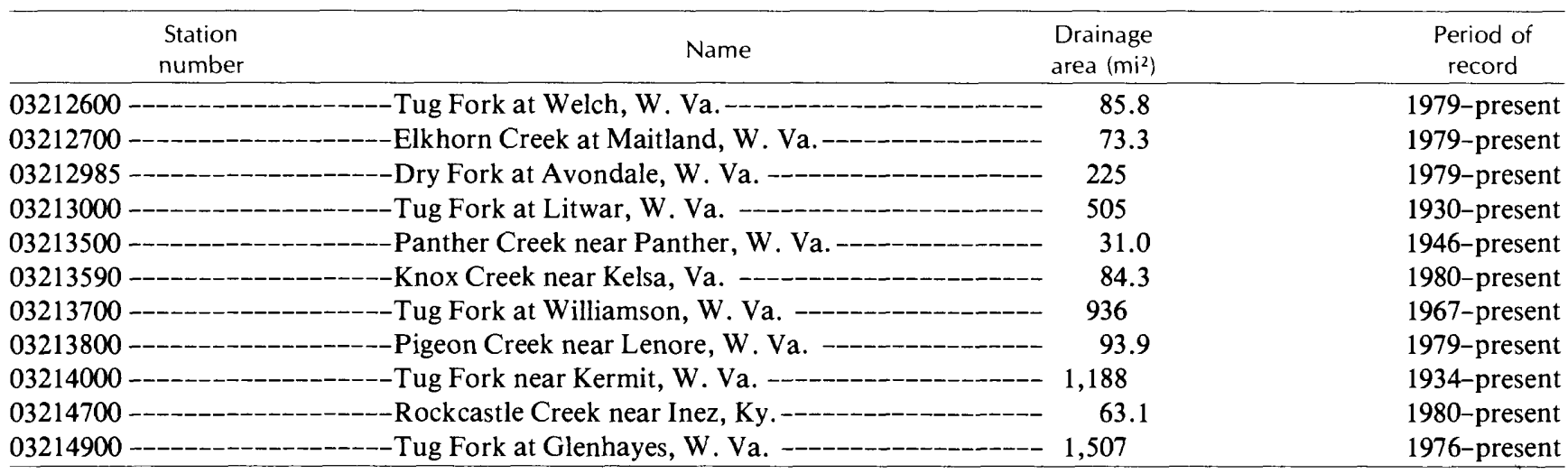



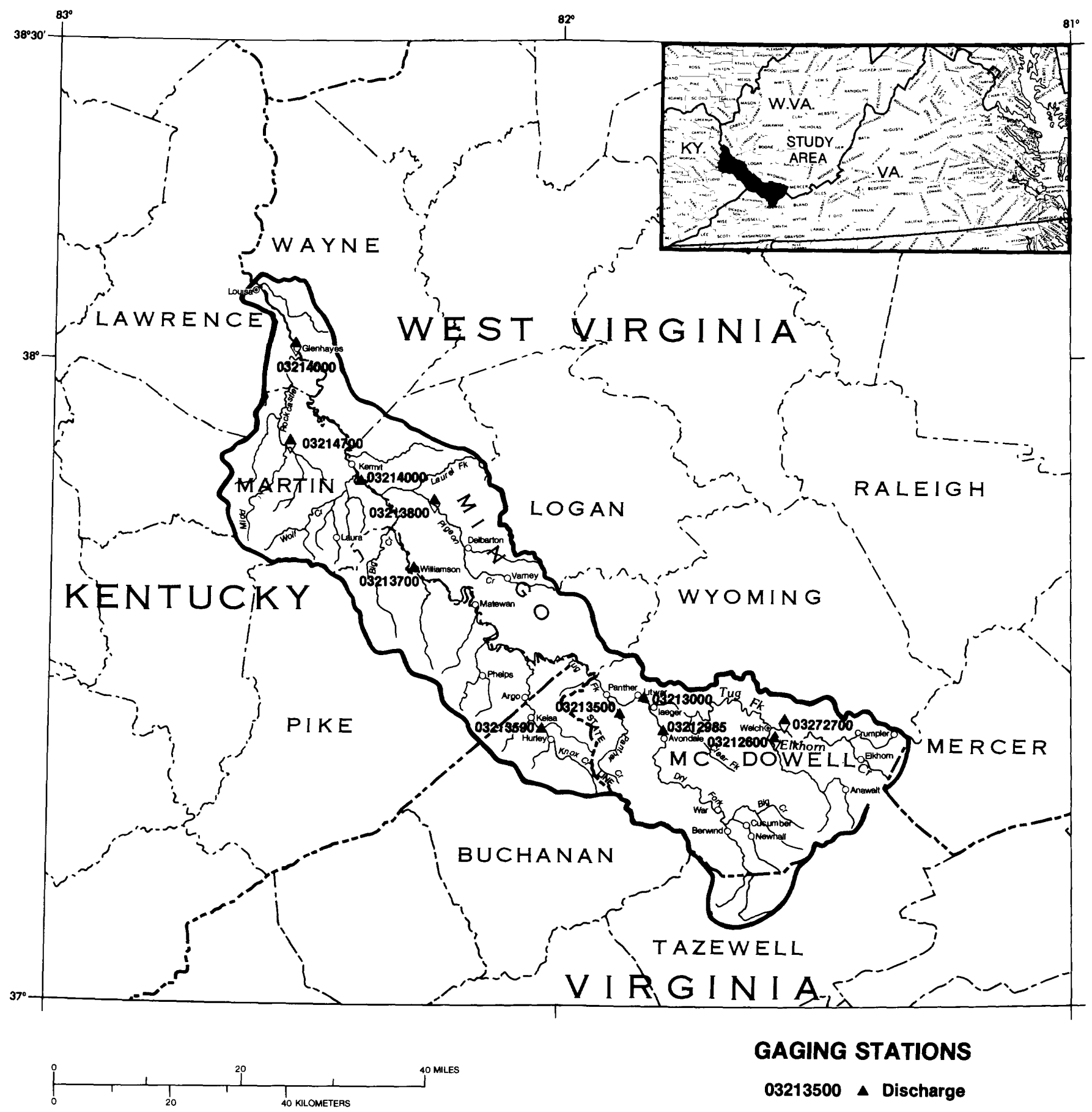

GAGING STATIONS

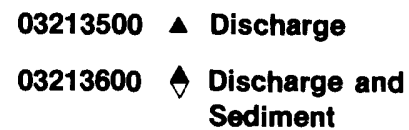

Figure 5. Location of continuous-record streamflow-gaging stations in the Tug Fork basin.

An explanation of these categories is contained in U.S. Geological Survey Professional Paper 964, "A Land Use and Land Cover Classification System for Use with Remote Sensor Data" (Anderson and others, 1976). Table 4 shows the area and percent of the total basin devoted to each of these land-use categories for the 1973-76 period.
The largest single classification in the basin is "deciduous forest." However, areas of streams and channels are not included, and areas of strip mining may be underestimated because of mapping limitations. Only waterways of over 660 feet in width and over 10 acres in extent are identified. Also, the areal extent of surface mining determined from these maps may not 
Table 3. Suspended-sediment stations in the Tug Fork basin

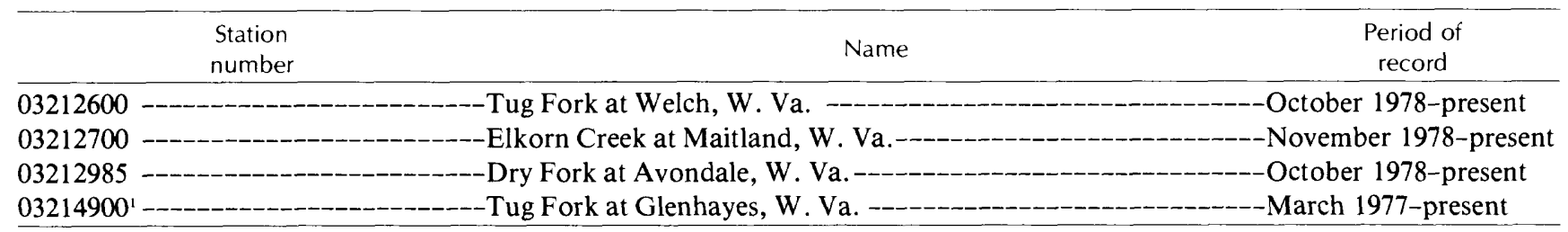

' The maximum observed daily suspended-sediment load at station 03214900 for the period of record was 320,000 tons on April 5, 1977; minimum was 2.2 tons on September 29 and 30, 1978. Maximum observed daily mean concentration was 4,020 mg/L on April 5, 1977; minimum daily mean was $4 \mathrm{mg} / \mathrm{L}$ on September 29 and 30, 1978. Continuous data on specific conductance also are collected at station 03214900 .

reflect the total area of surface disturbance due to mining because only mines that have widths greater than 660 feet and that cover areas greater than 10 acres are mapped. Another estimate of the area affected by surface mining is 50,000 to 80,000 acres or 5 to 8 percent of the basin area (Tug Valley Recovery Center, 1978). A quantitative history of land use in the Tug Fork basin is being developed.

It is not possible, at the present time, to quantitatively describe the history of land disturbance by surface mining. However, information on surface-coal production is available on a county-by-county basis (R. E. Harris, U.S. Department of Energy, written commun., 1980). Two time-series of annual surface-coal production were developed from these data. The first is for the Tug Fork basin upstream of Litwar, W. Va. The sur-

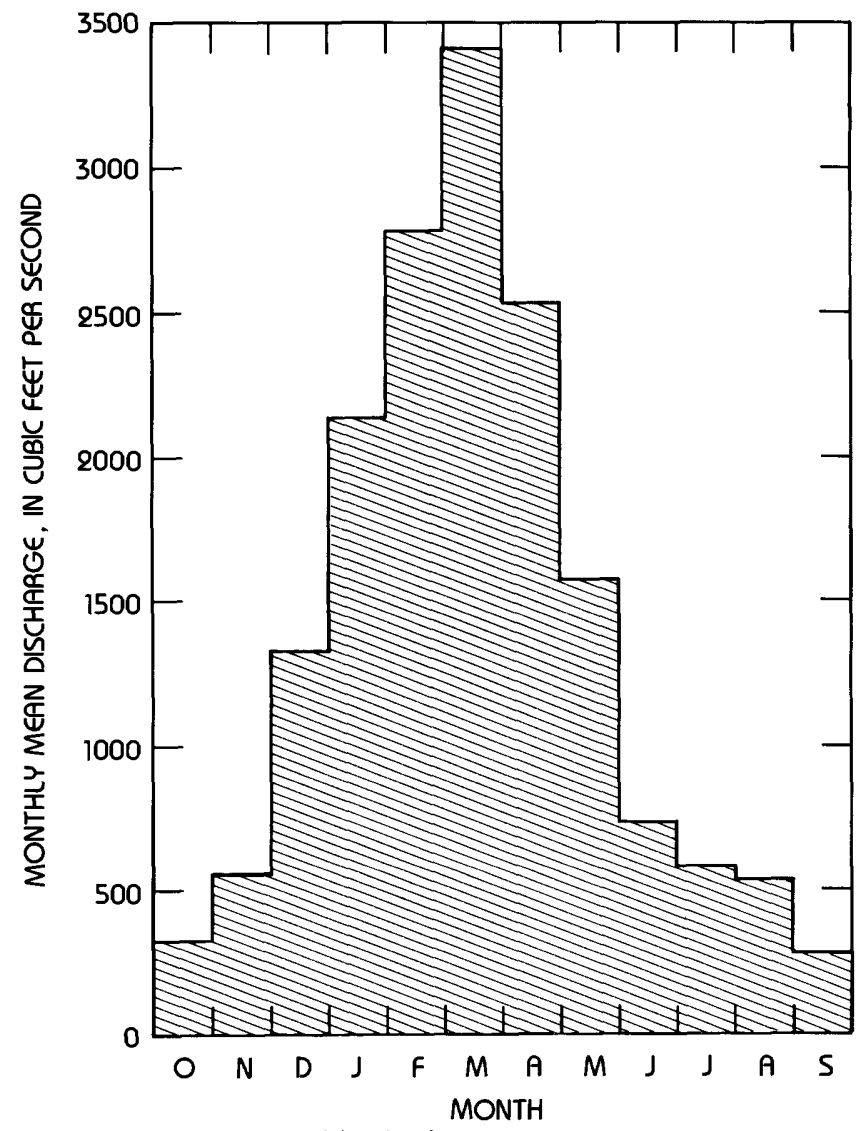

Figure 6. Mean-monthly discharges (1934-77) at gaging station 03214000 Tug Fork near Kermit, W. Va. face-coal production for the first series is assumed to be equal to the production of McDowell County, W. Va. The second series is for the Tug Fork basin upstream of Kermit, W. Va. The surface-coal production in this case is assumed to be equal to the sum of the production of McDowell County, W. Va.; 23 percent of the Buchanan County, W. Va., production; 28 percent of the Pike County, Ky., production; and 76 percent of the Mingo County, W. Va., production. These percentages represent the percentage of the total area of each county in the basin. The accuracy of these latter two time-series is unknown because information on the spatial distribution of production in the various counties over the years was not available. In addition, these time-series may not accurately measure land disturbance. Mining practices have changed over the years due to technological and regulatory changes so that the effect on the landscape of a ton of coal mined in 1947 may be very different from the effect of a ton mined in 1978. The two coal-production time-series are shown in table 5 and figure 10.

The Litwar production figures show a rapid rise from the early 1940's, peaking in 1951. Later highs in 1957 and 1967-70 and lows in 1959 and 1974 followed. For the period 1948-78, there has been no secular increase or decrease, only a series of fluctuations. The Kermit production figures are similar to the Litwar figures from the 1940's. However, the Kermit production figure rose and remained high through the 1970's, while the Litwar figures remained relatively constant.

Table 4. Land use in the Tug Fork basin for 1973-76 (U.S. Army Corps of Engineers, 1979)

\begin{tabular}{|c|c|c|}
\hline USGS land use category & Acres $^{1}$ & $\begin{array}{c}\text { Percent } \\
\text { of } \\
\text { total }\end{array}$ \\
\hline Urban or built-up land & 34,099 & 3.4 \\
\hline Crop and pasture land & 5,325 & 0.5 \\
\hline Deciduous forest & 907,930 & 91.6 \\
\hline Mixed forest - & 9,523 & 1.0 \\
\hline Reservoirs --_-_- & 307 & $\left({ }^{2}\right)$ \\
\hline Strip mines, quarries, and gravel pits- & 25,702 & 2.6 \\
\hline Transitional areas- & 9,114 & .9 \\
\hline Total ------ & 992,000 & 100.0 \\
\hline
\end{tabular}

${ }^{1}$ Figures are estimates using an areagraph chart that has 97-percent accuracy.

${ }^{2}$ Less than 0.1 percent. 


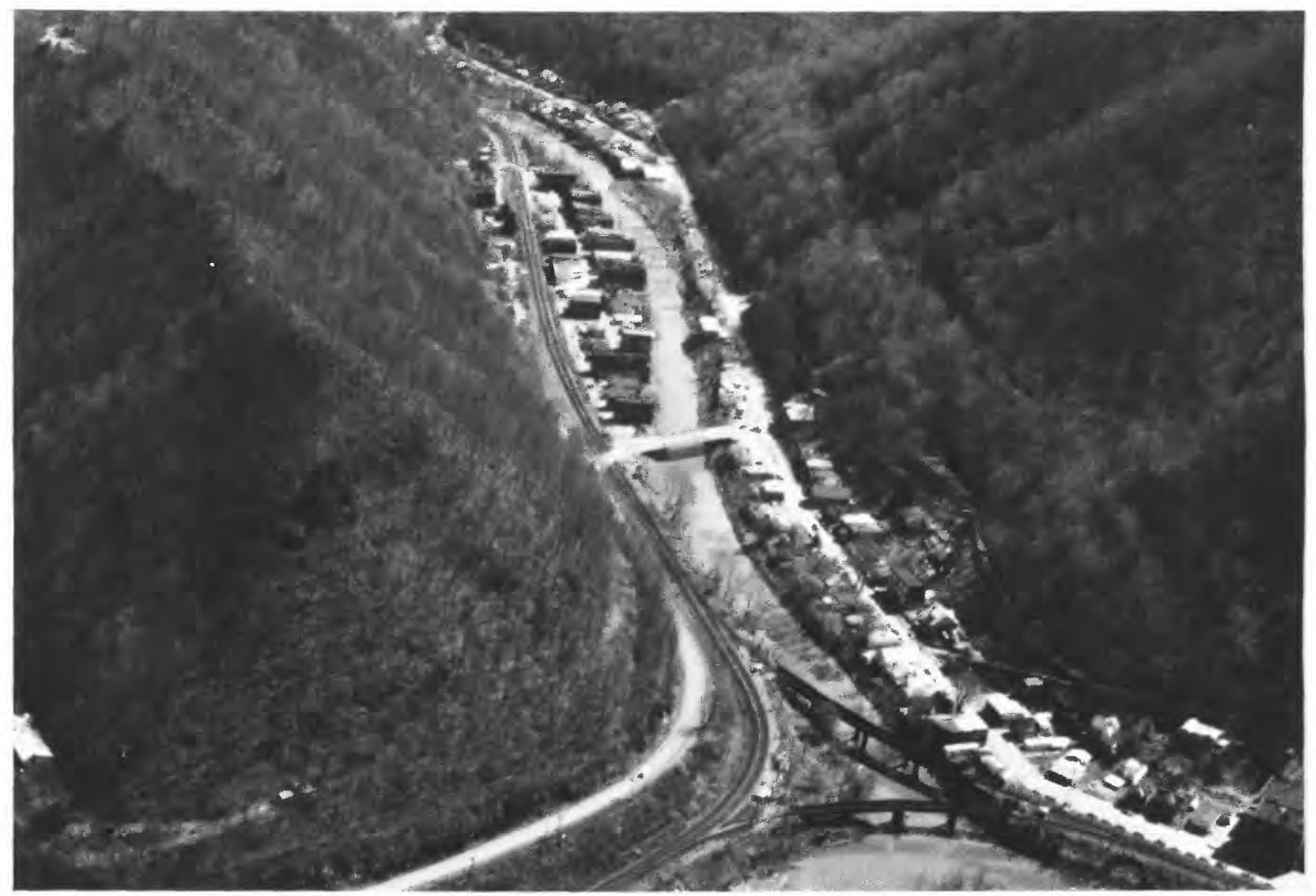

Figure 7. Urban and highway utilization of the flood plain along Tug Fork.

\section{STATISTICAL ANALYSIS}

Statistical analyses were employed to explore the general hypothesis that the flooding characteristics of the Tug Fork basin have changed over time. Changes in flooding characteristics, if they have occurred, can be attributed to either of two general causes (or both). The first cause is meteorological; that is, changes in the frequency distribution of storm rainfall (perhaps coupled with snowmelt conditions). Finding that such factors have caused a change in flooding characteristics sheds no light on future flooding characteristics if one cannot foretell the future of storm-rainfall characteristics. The second possible cause is a change in the hydrologic response arising from changes in (for example) infiltration rates, soil moisture capacities, integration of the drainage network, channel roughness, or some combination of these. If the second were the cause of a change in flooding, then the future flooding characteristics could be predicted on the basis of projections of the future status of these hydrologic response characteristics.
In the sections entitled "Analysis of Annual Flood Series" and "Analysis of Partial-Duration Series," the question of trend in flooding is considered without regard to cause. The section "Multiple-Regression Methods" shifts the focus to trends in the hydrologic response. The first analyses provide a basic background description of what has occurred. The multiple-regression analysis then focuses on cause; that is, meteorological versus hydrologic response.

\section{Analysis of Annual-Flood Series}

Three stream gaging stations in the Tug Fork basin have collected more than 20 years of annual-flood data: 03213000 Tug Fork at Litwar, W. Va. (1931-79), 03213500 Panther Creek near Panther, W. Va. (1947-79), and 03214000 Tug Fork near Kermit, W. Va. (1935-79). The locations of these stations are shown in figure 5. The annual-flood-series data for these stations are plotted in figures 11,12 , and 13 and are listed in appendixes $\mathrm{A}$ to $\mathrm{E}$. The two stations on the Tug Fork are located downstream of substantial areas (perhaps as 


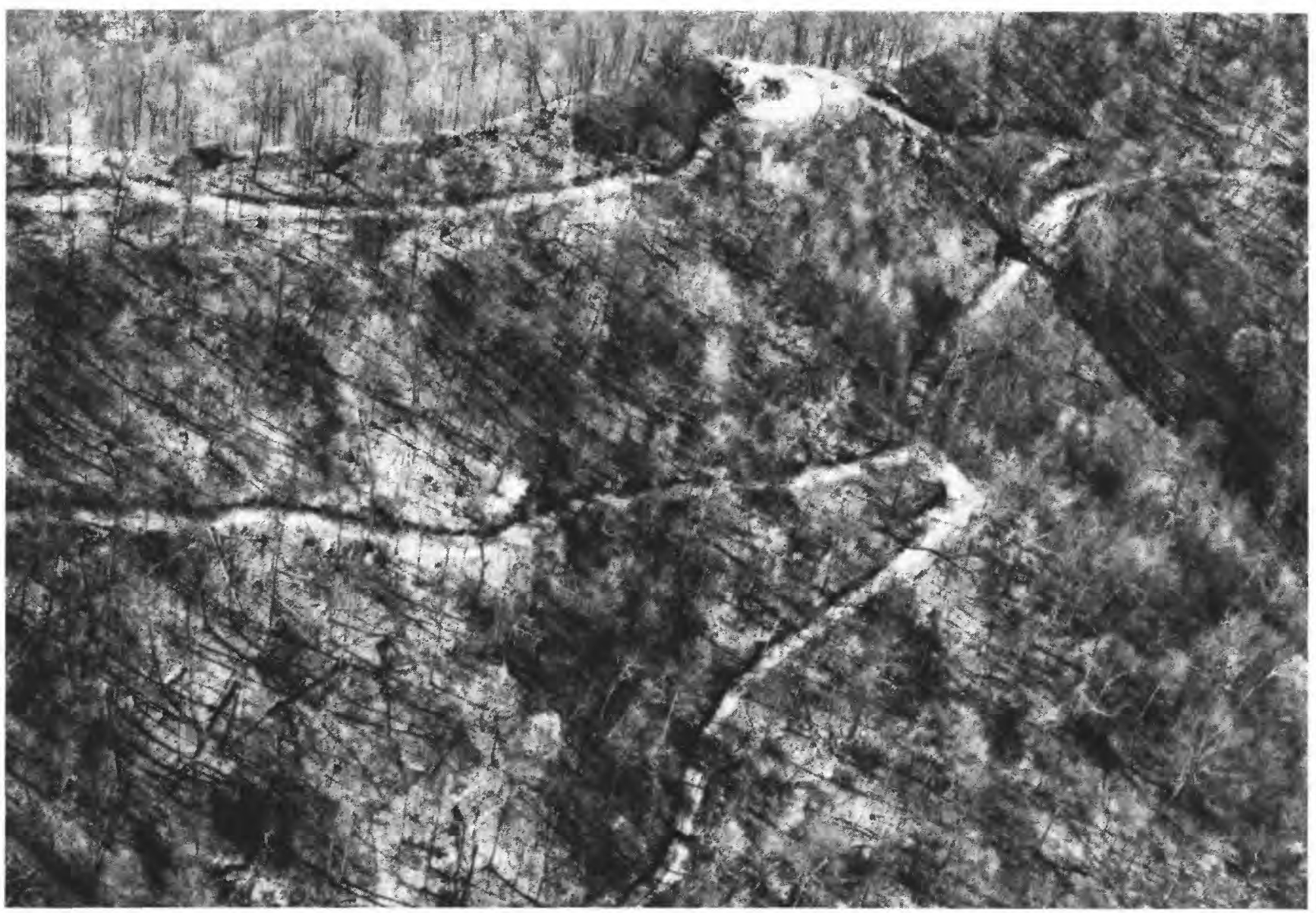

Figure 8. Logged area in the Tug Fork basin.

much as 8 percent of the basin) of surface-mined land. In contrast, most of the basin above the Panther Creek station is in Panther State Forest and is not subject to mining. Less than 1 percent of this basin has been disturbed by mining, and in 1980 all of it was revegetated.

The first question of interest is whether the floodfrequency distribution has been constant over time. If the frequency distribution is constant, then the probability of exceeding any specified discharge is the same from one year to the next. A good method for evaluating these annual-flood data for trend (change in floodfrequency distribution) is the Mann-Kendall test for trend (Bradley, 1968). The Mann-Kendall test for trend was selected because, unlike classical tests such as the t-test, it does not assume that the random variable (flood magnitude) is normally distributed. Clearly all three flood series violate this assumption of normality (see the skewness coefficients in table 6). Where the data arise from a nonnormal highly skewed population with trend, the Mann-Kendall test is more powerful than the classical tests. The Mann-Kendall test is not as sensitive to the abnormally large value of the 1977 flood as a classical test would be.
The null hypothesis of the Mann-Kendall test is that the data are random samples that are independent and identically distributed. The statistic $\tau$ reported here is a measure of association between the random variable (annual-flood discharge) and time. Kendall (1975) refers to it as a measure of rank correlation. It is like the product-moment correlation coefficient in that $|\tau| \leq 1$ and, when the discharges are identically distributed over all values of time, the expected value of $\tau$ is zero.

At all three stations, the value of $\tau$ is positive (suggesting upward trend) and is significant at the 10-percent (two-sided) significance level. The value of $\tau$ and associated $p$ value (probability of $|\tau|$ being greater than or equal to the given $\tau$ value under the null hypothesis) are given in table 6, with some summary statistics characterizing the annual-flood series at the three stations.

All of the associated $p$ values (or "significance levels") are small; the largest is 0.066 . Thus, chance variation of floods are not likely to produce $r$ values this large, and, therefore, the results at all three stations indicate trend. A useful graphical refinement of the basic time-series plots in figures 11 to 13 is to break the 


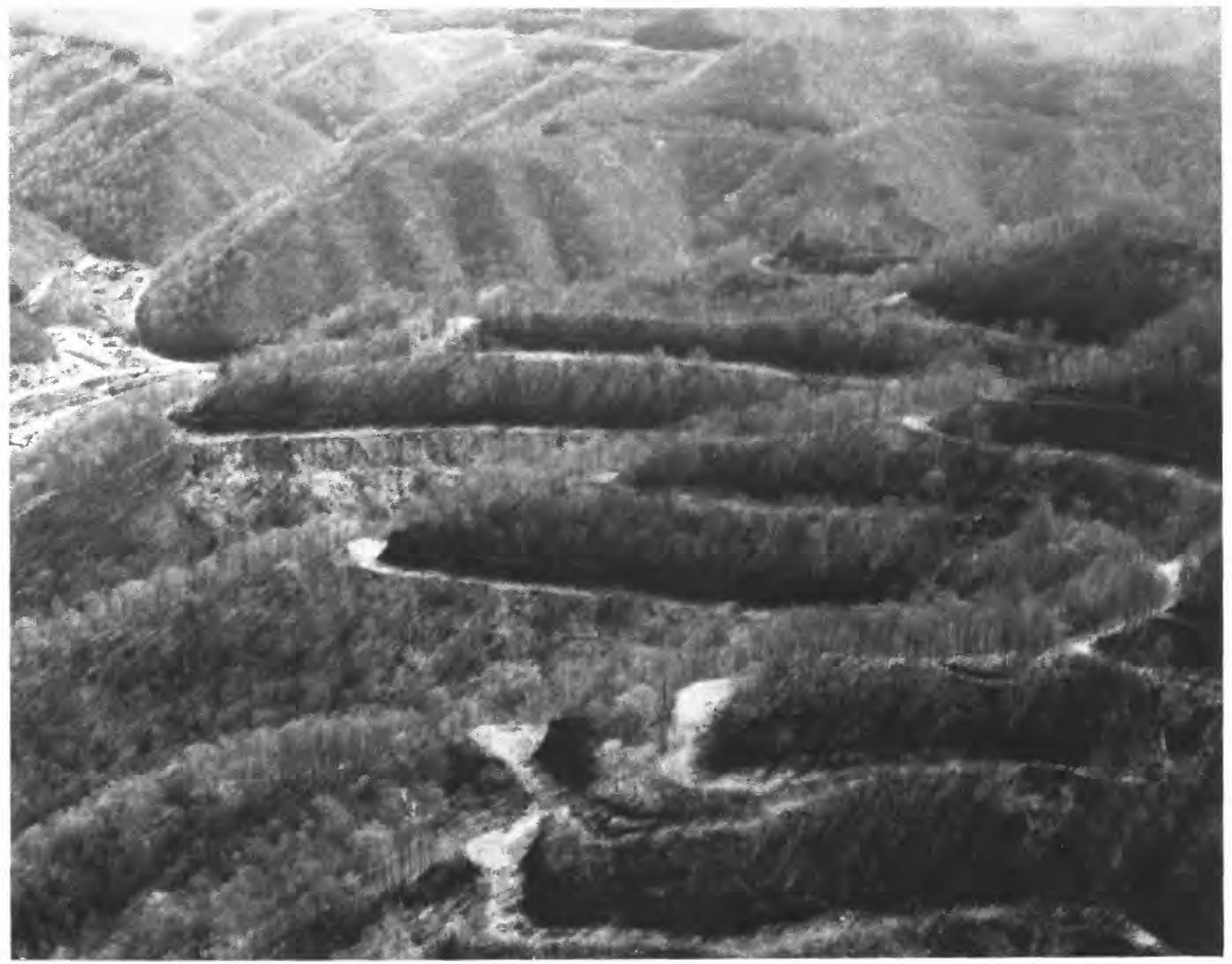

Figure 9. Surface-mined area in the Tug Fork basin.

records into different periods-1931-46, 1947-63, and 1964-79 were selected-and then construct box plots (Kleiner and Graedel, 1980) for each period as shown in figure 14. The box plots show the median (line inside the box), upper and lower quartiles (ends of the box), and minimum and maximum values (bars at the ends of dash lines). For all three stations, there is an increase from one period to the next in the lower, median, and upper quartile and in maximum values (with the exception of the lower quartile value for the Kermit gage, which is slightly lower in the 1947-63 period than in the pre-1947 period). These box plots show a general upwards movement of the flood-frequency distributions, with some suggestion of a greater increase in the high extremes than in the central portion of the distribution and little apparent change in the low extreme.

The Mann-Kendall test for trend and the box plots suggest that there has been an upwards trend in the distributions at all three stations. The apparent presence of the trend at the Panther Creek gage complicates the interpretation. If trend were a result of surface mining, then one would expect to find no trend at the Panther Creek gage. If trend were at least partly a result of climatic causes, then one might expect to find trend at all three gages because all are responding to closely related meteorological conditions (because of their proximity).

Trend tests were performed on rainfall data associated with the annual flood events. The rainfall data used are for maximum 2-day rainfall that caused the annual flood at the stream-gaging station (see appendixes A-E). The stream-gaging stations and their associated rainfall stations are listed in table 7 . The results of the Mann-Kendall tests (table 7) show that, at all three stations, there is no statistically significant trend (at the 0.10 level) in the annual flood-producing rainfall amounts. However, the positive values of $\tau$ suggest that there is a preponderance of larger rainfall values in the later years. 
In summary, these results show strong evidence of trend in flood discharge and very weak evidence of trend in the rainfall producing the floods. The section "Multiple-Regression Methods" of this report will proceed from these observations to investigate the hypothesis that there has been a change in the hydrologic response characteristics of the Tug Fork.

Table 5. Annual surface-coal production, in millions of tons, Tug Fork basin, West Virginia, Kentucky, and Virginia

\begin{tabular}{|c|c|c|}
\hline \multirow[b]{2}{*}{ Year } & \multicolumn{2}{|c|}{$\begin{array}{l}\text { Annual production } \\
\text { in millions of tons }\end{array}$} \\
\hline & $\begin{array}{c}\text { Basin } \\
\text { above } \\
\text { Litwar, W. Va. }\end{array}$ & $\begin{array}{c}\text { Basin } \\
\text { above } \\
\text { Kermit, W. Va. }\end{array}$ \\
\hline 1940 & 0.00 & 0.00 \\
\hline 1941 & 0.00 & 0.00 \\
\hline 1942 & 0.00 & 0.00 \\
\hline 1943 & 0.00 & 0.10 \\
\hline 1944 & 0.01 & 0.17 \\
\hline 1945 & 0.11 & 0.35 \\
\hline 1946 & 0.04 & 0.52 \\
\hline 1947 & 0.06 & 0.87 \\
\hline 1948 & 0.58 & 1.56 \\
\hline 1949 & 0.87 & 1.21 \\
\hline 1950 & 0.84 & 1.21 \\
\hline 1951 & 1.05 & 1.32 \\
\hline 1952 & 0.69 & 0.84 \\
\hline 1953 & 0.63 & 0.85 \\
\hline 1954 & 0.62 & 0.97 \\
\hline 1955 & 0.60 & 1.10 \\
\hline 1956 & 1.08 & 1.77 \\
\hline 1957 & 1.50 & 2.37 \\
\hline 1958 & 0.85 & 1.21 \\
\hline 1959 & 0.34 & 0.66 \\
\hline 1960 & 0.60 & 0.91 \\
\hline 1961 & 0.61 & 0.89 \\
\hline 1962 & 0.62 & 1.18 \\
\hline 1963 & 0.77 & 1.74 \\
\hline 1964 & 1.09 & 2.35 \\
\hline 1965 & 0.78 & 1.76 \\
\hline 1966 & 1.16 & 2.60 \\
\hline 1967 & 1.39 & 2.85 \\
\hline 1968 & 1.49 & 2.68 \\
\hline 1969 & 1.37 & 2.58 \\
\hline 1970 & 1.48 & 3.52 \\
\hline 1971 & 1.01 & 3.88 \\
\hline 1972 & 0.86 & 3.51 \\
\hline 1973 & 0.70 & 3.10 \\
\hline 1974 & 0.36 & 3.83 \\
\hline 1975 & 0.77 & 3.46 \\
\hline 1976 & 0.97 & 3.84 \\
\hline 1977 & 0.86 & 3.41 \\
\hline 1978 & 0.60 & 2.43 \\
\hline
\end{tabular}

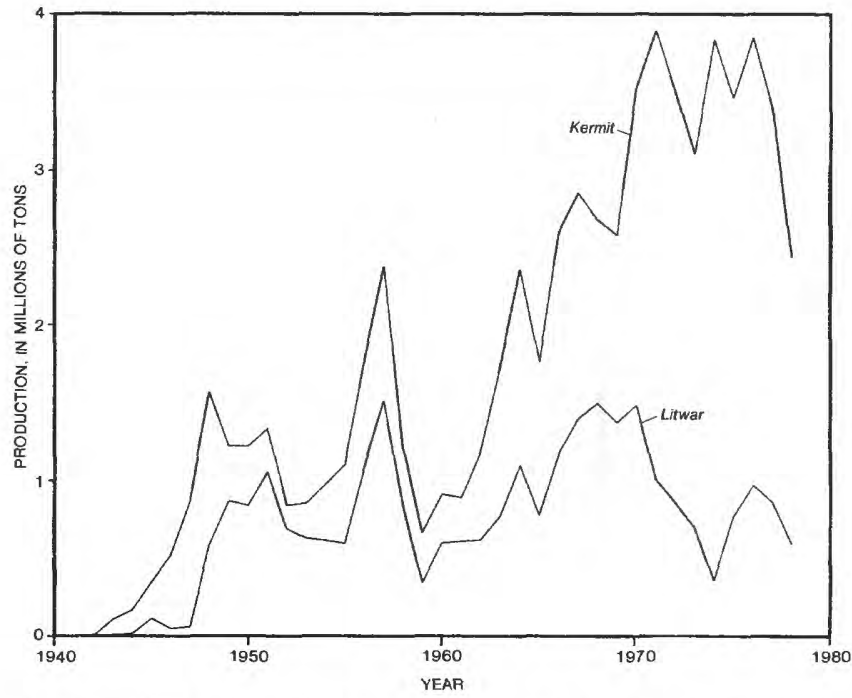

Figure 10. Annual surface-coal production, in millions of tons, Tug Fork basin, West Virginia, Kentucky, and Virginia. Upper line is basin above Kermit, W. Va. Lower line is basin above Litwar, W. Va.

\section{Analysis of Partial-Duration Series}

In addition to searching for trends in the magnitude of annual floods, an attempt also was made to identify trends in the number of times each year that floods exceeded certain threshold values at Kermit, Litwar, and Panther, W. Va. These historic exceedance frequencies (or partial-duration series) were examined for two different thresholds at each of these three stream-gaging sites. As in the box-plot analysis of the section entitled "Analysis of Annual-Flood Series," each record was broken into three periods-1931-46, 1947-63, and 1964-79-and then examined for evidence of systematic increases or decreases in average annual exceedance frequencies across the three periods. Some changes in statistical presentation are appropriate because frequency data are considered rather than magnitude data.

For each stream site, threshold discharge, and time period, exceedance frequencies were assumed to follow a Poisson distribution. This is a common assumption in analysis of partial-duration series (see, for example, Shane and Lynn, 1964), and standard statistical tests of goodness-of-fit (Snedecor and Cochran, 1967, p. 236-237) show no reason to discard the Poisson assumption. Both references discuss the properties of the Poisson distribution in detail.

Figure 15 shows the average annual frequencies of exceedance for the different thresholds and different 


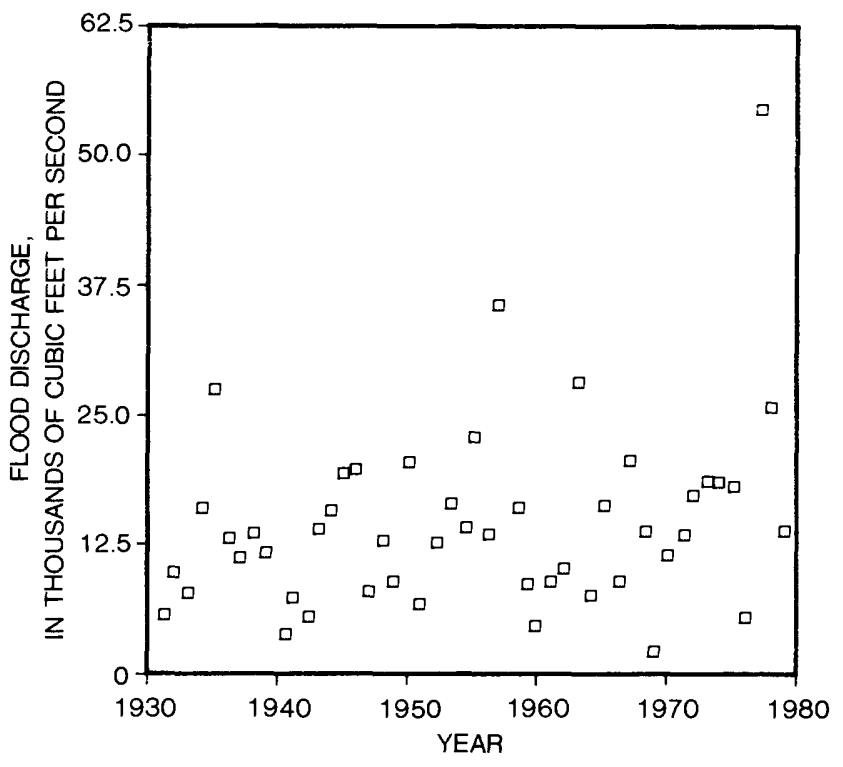

Figure 11. Annual-flood-series data for Tug Fork at Litwar, W. Va., 1931-79 (03213000).

time periods, together with 95-percent confidence intervals based on the Poisson assumption (Johnson and Kotz, 1969). The line in the center of each box represents the average exceedance frequency. The ends of each box represent the ends of the 95-percent confidence intervals for mean exceedance frequencies. As a rule of thumb, the average exceedance frequencies in two different periods differ significantly relative to basic yearto-year variation when the confidence-interval ends do not overlap the average exceedance frequencies. For the different time periods and threshold values in figure 15 , this occurs only for the Kermit series with a $20,000-\mathrm{ft}^{3} / \mathrm{s}$ threshold (that is, compare the interval for 1931-46 with the interval for 1964-79) and for the Litwar series with a $6,000-\mathrm{ft}^{3} / \mathrm{s}$ threshold.

Table 8 gives some formal statistical measures of the differences between average exceedance frequencies in different time periods relative to basic year-to-year variation. Two difference hypotheses are examined: (1) the distribution of exceedance frequencies is different in 1964-79 from that in 1947-63 or (2) the distribution of exceedance frequencies is different in 1964-79 from that of all previous years.

Statisticians examine the significance of such differences in different ways. According to some (Akaike, 1970; Edwards, 1972), the log-likelihood ratio statistic should be examined for either of the two hypotheses relative to the hypothesis that the distribution of exceedance frequencies is the same for all periods. If this

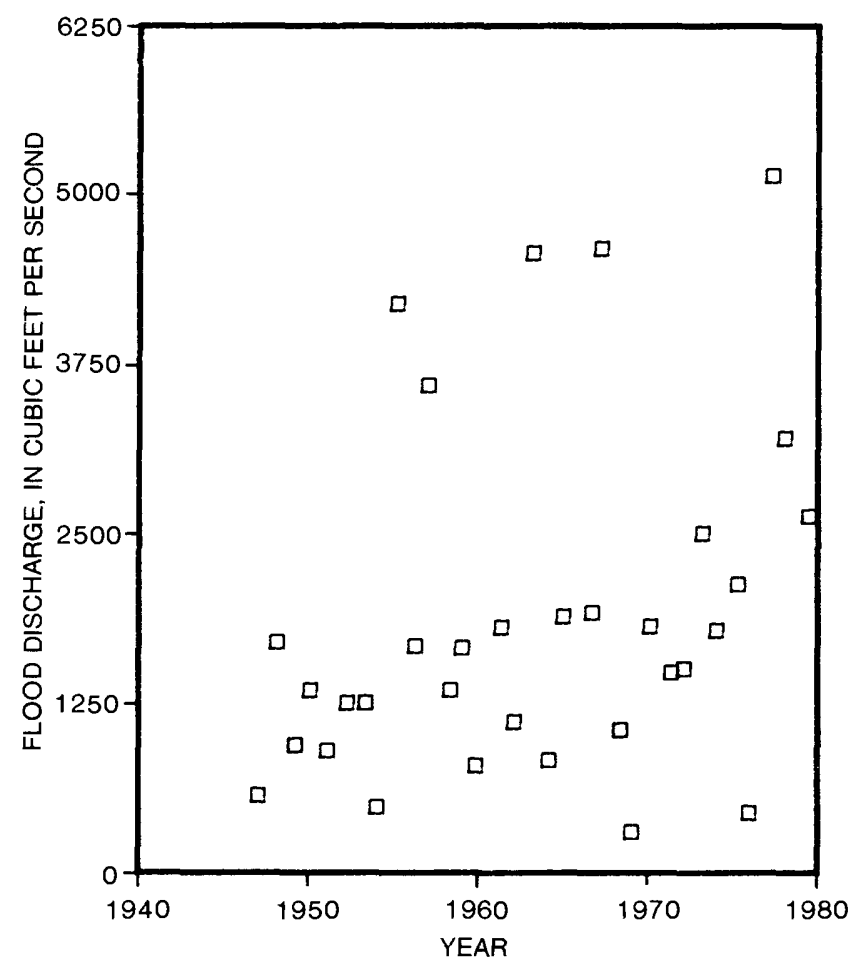

Figure 12. Annual-flood-series data for Panther Creek near Panther, W. Va., 1947-79 (03213500).

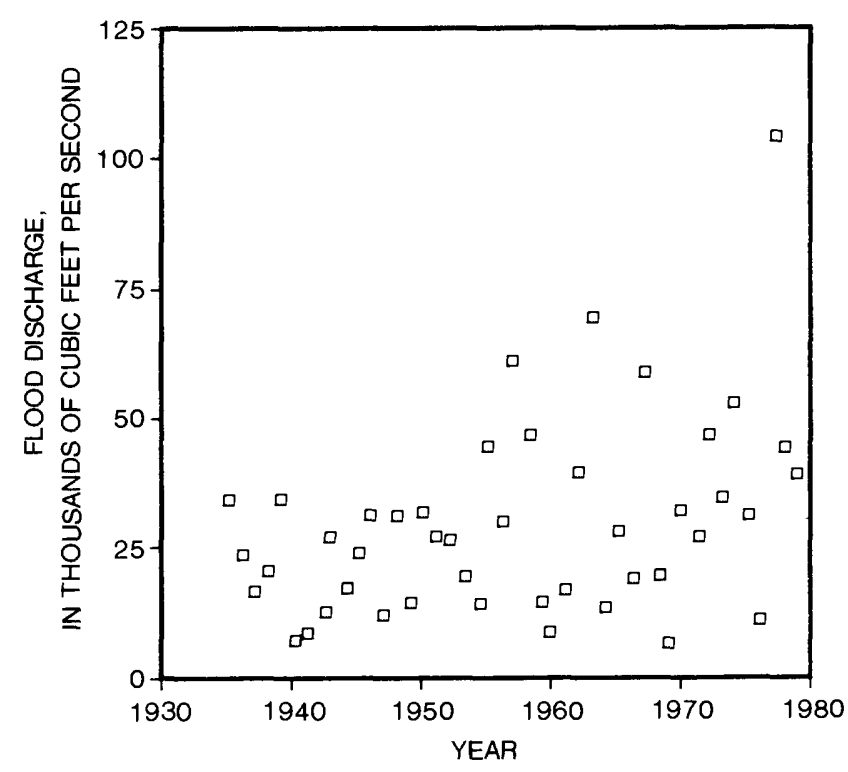

Figure 13. Annual-flood-series data for Tug Fork near Kermit, W. Va., 1935-79 (03214000). 
Table 6. Statistics of annual-flood series

\begin{tabular}{|c|c|c|c|c|c|c|c|c|c|c|c|c|}
\hline \multirow[t]{2}{*}{ Location } & \multirow{2}{*}{$\begin{array}{l}\text { Record } \\
\text { length in } \\
\text { years }\end{array}$} & \multirow{2}{*}{$\begin{array}{c}\text { Average } \\
\left(\mathrm{ft}^{3} / \mathrm{s}\right)\end{array}$} & \multirow{2}{*}{$\begin{array}{c}\text { Standard } \\
\text { deviation } \\
\left(\mathrm{ft}^{3} / \mathrm{s}\right)\end{array}$} & \multirow{2}{*}{$\begin{array}{l}\text { Coeffi- } \\
\text { cient of } \\
\text { skewness }\end{array}$} & \multirow{2}{*}{$\begin{array}{l}\text { Coeffi- } \\
\text { cient of } \\
\text { kurtosis }\end{array}$} & \multirow{2}{*}{$\begin{array}{l}\text { Minimum } \\
\left(\mathrm{ft}^{3} / \mathrm{s}\right)\end{array}$} & \multirow{2}{*}{$\begin{array}{l}\text { Lower } \\
\text { quartile } \\
\left(\mathrm{ft}^{3} / \mathrm{s}\right)\end{array}$} & \multirow{2}{*}{$\begin{array}{l}\text { Median } \\
\left(\mathrm{ft}^{3 / \mathrm{s}}\right)\end{array}$} & \multirow{2}{*}{$\begin{array}{c}\text { Upper } \\
\text { quartile } \\
\left(\mathrm{ft}^{3 / \mathrm{s}}\right)\end{array}$} & \multirow{2}{*}{$\begin{array}{l}\text { Maximum } \\
\left(\mathrm{ft}^{3} / \mathrm{s}\right)\end{array}$} & \multicolumn{2}{|c|}{$\begin{array}{l}\text { Mann-Kendall test } \\
\text { for trend }\end{array}$} \\
\hline & & & & & & & & & & & $\tau$ & $p$ \\
\hline $\begin{array}{l}\text { Tug Fork at Lit- } \\
\text { war, W. Va. } \\
\text { Panther Creek }\end{array}$ & 49 & 14,700 & 8,800 & 206 & 9.48 & 0 & 0 & 13 & 0 & 0 & 0.182 & 0.066 \\
\hline $\begin{array}{l}\text { near Panther, } \\
\text { W. Va. - } \\
\text { Tug Fork near }\end{array}$ & 33 & 1,900 & 1,250 & 1.16 & 3.45 & 308 & 1,060 & 1,660 & 2,130 & 5,140 & 0.269 & 0.029 \\
\hline Kermit, W. Va. - & 45 & 29,700 & 18,600 & 1.65 & 6.84 & 6,760 & 16,700 & 27,000 & 34,600 & 104,000 & 0.236 & 0.023 \\
\hline
\end{tabular}

statistic exceeds 2 , the hypothesis of a change is strongly supported by the data. The highest log-likelihood ratio in table 8 is only 0.96 (ratio for the Kermit $20,000 \mathrm{ft}^{3} / \mathrm{s}$ series).

Other statisticians recommend examining the significance level associated with each log-likelihood ratio (Kendall and Stuart, 1973). This significance level is the approximate probability that a greater difference in average exceedance frequencies between time periods occurs by chance alone, given basic year-to-year variation. The only significance levels below 20 percent for the three stream-gaging stations are those for the Litwar and Kermit series with the larger base flows.

The data for Tug Fork suggest an upward trend in frequency of larger floods at Litwar and Kermit. But even under the mild requirement of a 10-percent significance level, these results are not statistically significant.

\section{Multiple-Regression Methods}

Analysis of annual-flood-series and partialduration-series data indicated an upwards trend in annual-peak-flood sizes at the Litwar, Kermit, and Panther gages. The Litwar and Kermit stream gages are located on Tug Fork below areas of substantial surfacemining activity. The Panther stream gage is on Panther Creek, a tributary of Tug Fork, below a relatively undisturbed area.

Increases in peak-flood size could be caused by increases in storm rainfall or by changes in the hydrologic response. Changes in the hydrologic response result from changes in vegetation cover (affecting interception of rainfall) or from changes in surficial characteristics of the watershed (for example, relative amounts of soil, bare rock, fractured rock, manmade pavements), changes in porosity and permeability of surficial deposits, and changes in integration and density of the drainage networks. Land-use practices (including farming, timber harvesting, urban development, road building, surfacecoal mining, and mine reclamation) change many of
FLOOD DISCHARGE, IN THOUSANDS OF CUBIC FEET PER SECOND

\begin{tabular}{lllllll}
0 & 20 & 40 & 60 & 80 & 100 & 120 \\
\hline
\end{tabular}

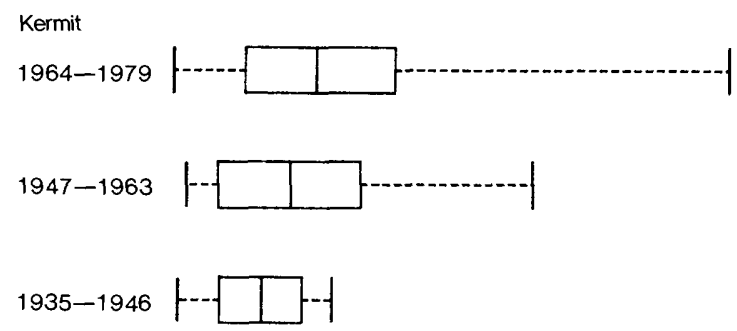

FLOOD DISCHARGE, IN THOUSANDS OF CUBIC FEET PER SECOND
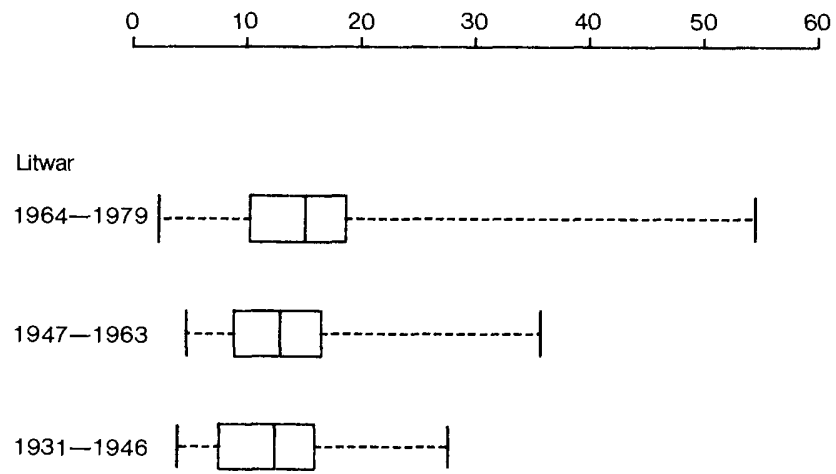

FLOOD DISCHARGE, IN THOUSANDS OF CUBIC FEET PER SECOND

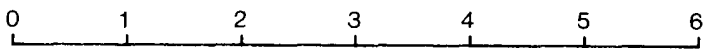

Panther

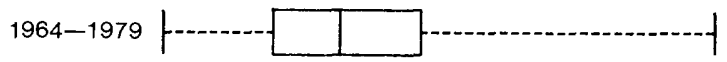

1947-1963 |--- $\square$

Figure 14. Box plots of annual-flood data for three streamgaging stations on Tug Fork, for three time periods. Box plots show the extreme values, quartiles, and medians of each sample. 
Table 7. Trends in the maximum 2-day rainfall associated with the annual flood

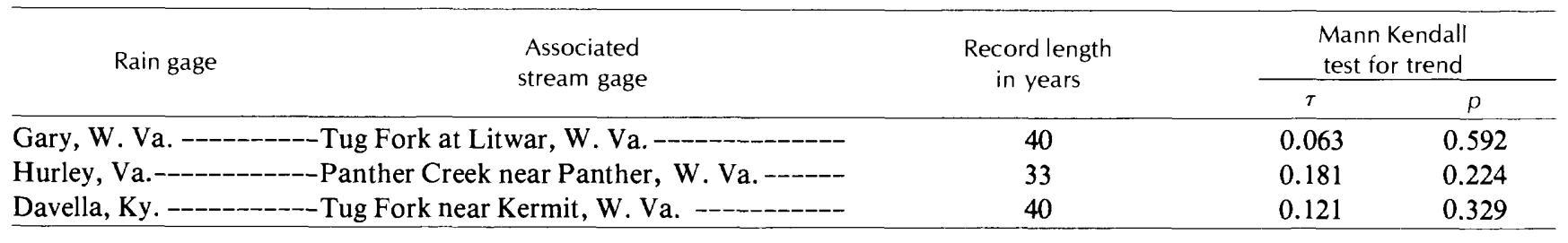

1964-79

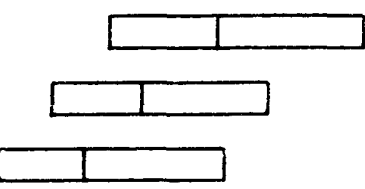

Kermit $20,000 \mathrm{ft}^{3} / \mathrm{s} \quad 1947-63$

1931-46

1964-79

Kermit $10,000 \mathrm{ft}^{3} / \mathrm{s} \quad 1947-63$

1931-46

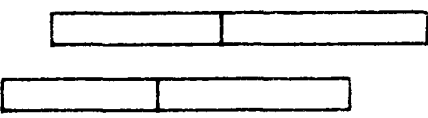

$1931-46$

1964-79

Litwar $10,000 \mathrm{ft}^{3} / \mathrm{s} \quad 1947-63$

1931-46

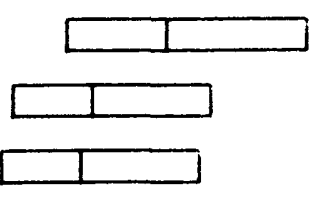

1964-79

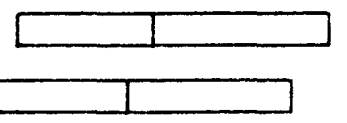

Litwar $6,000 \mathrm{ft}^{3} / \mathrm{s} \quad 1947-63$

1931-46

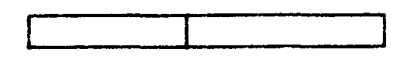

1964-79

Panther $1,500 \mathrm{ft}^{3} / \mathrm{s} \quad 1947-63$

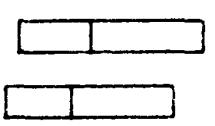

$1964-79$

Panther $700 \mathrm{ft}^{3} / \mathrm{s} \quad 1947-63$
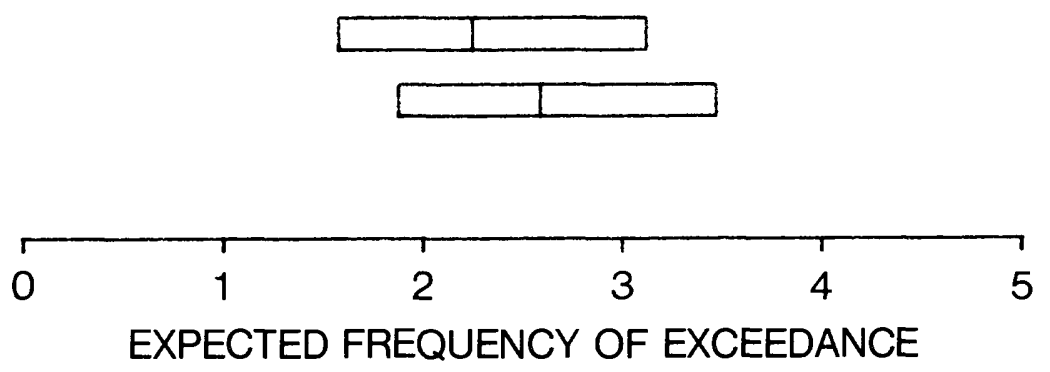

Figure 15. Expected frequencies of exceedance for different thresholds and time periods for three stream-gaging stations on Tug Fork. The boxes denote 95-percent confidence intervals for the expected frequencies. 
these characteristics and, therefore, change the basin flood response. For any change in land use, the corresponding change in flood response is not immediately clear (either for magnitude or direction of change). For example, Bryan and Hewlett (1981) report that, in small eastern Kentucky watersheds, surface-coal mining changed the hydrologic response, which, in turn, resulted in increased peak summer flows and slightly decreased peak winter flows.

If the hydrologic responses of the Panther Creek basin and of the Tug Fork basin above Litwar or Kermit do not change, then no change with time would be expected in the relation between concurrent annual-peak discharges for the basins. There would be some random variation around this relation depending on the variability over the basins of the flood-producing storms. This random variation limits the ability to detect a trend in the response of Tug Fork. This variation can be reduced by using the Tug Fork storm rainfall data. Regression methods were used to try to determine if there was a trend in the flood discharges of Tug Fork relative to those of Panther Creek that the Tug Fork rainfall data cannot explain.

The primary statistical tool used in investigating these relative flood trends was ordinary least-squares regression analysis (OLS). The following regression model was fitted to the annual-flood series at Litwar and Kermit:

$$
Q=b R+(c+d Y) P
$$

or

$$
Q=b R+c P+d Y P
$$

where second,

$Q$ is the annual-peak discharge in cubic feet per

$R$ is the maximum two-day rainfall in inches corresponding to the annual peak,

$P$ is the coincident peak discharge at Panther in cubic feet per second,

$Y$ is the year of the annual peak minus 1960 , and

$b, c$, and $d$ are the coefficients of the fitted equation.

The coefficients of fitted equations were examined for statistical significance by following the standard multiple-regression procedures found in many texts (for example, Draper and Smith, 1966). A significant value of $c$, for example, implies a significant relation of $Q$ to floods at Panther Creek. A significant value of $d$ indicates that this relation has changed since 1940.

The $Y P$ variable is referred to in regression analysis as the "interaction term." It is, in the above equation, also the relative trend term because a significant value of $d$ indicates a significant relative trend in annual-flood characteristics. This method of trend detection using interaction terms is described by Brown and others (1975).

Considerable effort was expended on selecting this regression equation as a reasonable descriptor of peakflood behavior at Litwar and Kermit. This model selection effort was both empirical-using stepwise regression techniques-and judgmental, because missing data prevented direct statistical comparison of some explanatory variables and because some variables seemed more reasonable for certain stream gages. Standard stepwise regression methods (Draper and Smith, 1966) and maximum $R^{2}$ improvement methods (Hocking, 1976) were used in the empirical model building.

\begin{tabular}{|c|c|c|c|c|c|}
\hline Site & $\begin{array}{c}\text { Number of } \\
\text { years }\end{array}$ & $\begin{array}{l}\text { Flood } \\
\text { series }\end{array}$ & $\begin{array}{l}\text { Alternative } \\
\text { hypothesis' }\end{array}$ & $\begin{array}{l}\text { Log-likelihood } \\
\text { ratio }\end{array}$ & $\begin{array}{c}\text { Significance } \\
\text { level }\end{array}$ \\
\hline \multirow[t]{3}{*}{ Kermit---------_---- } & 45 & $20,000 \mathrm{ft}^{3} / \mathrm{s}$ & $\mathrm{A} 2$ & 0.60 & 0.27 \\
\hline & & & A3 & 0.96 & 0.17 \\
\hline & & & A3 & 0.35 & 0.40 \\
\hline \multirow[t]{2}{*}{ Litwar -------------- } & 49 & $10,000 \mathrm{ft}^{3} / \mathrm{s}$ & $\mathrm{A} 2$ & 0.49 & 0.32 \\
\hline & & & A3 & 0.29 & 0.45 \\
\hline \multirow[t]{4}{*}{ Panther------------- } & 33 & $1,500 \mathrm{ft}^{3} / \mathrm{s}$ & $\mathrm{A} 2$ & 0.01 & 0.89 \\
\hline & & & A3 & 0.01 & 0.89 \\
\hline & & $700 \mathrm{ft}^{3} / \mathrm{s}$ & $\mathrm{A} 2$ & 0.37 & 0.39 \\
\hline & & & A3 & 0.37 & 0.39 \\
\hline
\end{tabular}

Table 8. Test statistics for expected frequencies of exceedance

' The null hypothesis is that the whole series comes from a single Poisson distribution. Alternative hypothesis A2 is that the Poisson distribution and expected exceedance frequency in 1964-79 differ from those in 1947-63. Alternative hypothesis A3 is that the Poisson distribution and expected exceedance frequency in 1964-79 differ from those in all years of record prior to 1964. 
Initially, attempts were made to explain as much of peak-flood variation as possible with only rainfall data. Nine different storm durations at eight different rain gages (fig. 5) were examined. Various functional forms involving logs and polynomials were considered.

Simply using the maximum 2-day storm duration served as well as any complicated linear combination of storm durations. Simple models seemed to account for as much as flood variation as could be explained by the data. Models with more than two rain gages did not provide a worthwhile improvement over simpler models. The rainfall record from Hurley, Va., near the center of the basin, was the best explanatory variable at all three stream gages. Davella, Ky., records were useful for the Kermit flood series and Gary, Va., records were useful for the Litwar flood series. This relation is exactly as would be expected from looking at the map of the basin in figure 5.

Rainfall models with as many as four rain gages as explanatory variables had $R^{2}$ values (percent of flood variation explained) below 70 percent. Models based on the final regression form have $R^{2}$ values as high as 86 percent and use fewer explanatory variables. These $R^{2}$ values are not strictly comparable because the regressions are computed with two different subsets of the data (because of missing data at various rain gages) and are computed with and without intercept terms (because the intercepts were never significant), changing the usual definition of $R^{2}$. Nonetheless, the size of the difference, coupled with the number of explanatory variables involved, gives a reasonable, though rough, guide to the improvement represented by the final model form.

Panther Creek flood discharges were included, in addition to rainfall, as an explanatory variable in the final equation for Litwar and Kermit. Using those discharges instead of Hurley, W. Va., rainfall data (the nearest rain gage) substantially improved model fit.

Finally, trend and interaction terms were added to the model to determine whether the relation of the flood series to the best explanatory variables changed over time. The intercept term, two of the interaction terms, and a year term were dropped from the final model as statistically insignificant.

Final regression analyses were performed on four different sets of data (see tables 9 and 10). For Litwar, the "standard data set" uses rainfall at the Gary, W. Va., rain gage and coincident flood peaks at Panther, W. Va., as explanatory variables. Because this information is available for only 29 annual-flood peaks at Litwar, an "augmented data set" also was constructed. Rainfall at Pikeville, Ky., was substituted for missing data at Gary. Estimated values of missing flood peaks at Panther were obtained from a regression relation between Panther flood peaks and rainfall at
Hurley, Va. Augmenting the standard data set in this way provided explanatory variables for 37 annual-flood peaks at Litwar. Results of regression analyses of relative trend at Litwar for both the standard and augmented data sets are shown in table 9 . Similarly, the data set for annual flood peaks at Kermit were augmented, and the regression results are shown in table 10. For Kermit, the standard data set has 25 observations, and the augmented data set has 37 observations. All four data sets are listed in the appendixes.

The 1977 Tug Fork flood peak at both Litwar and Kermit was enormous compared to those in the other years of record (see figs. 11-13). Statistical analyses should extract general patterns from data, but such an unusual observation can greatly influence the fit of a regression model. Where results of statistical analyses depend largely on one observation, they must be interpreted cautiously. A statistical technique that seeks to summarize in one pass a set of data that contains an outlying observation may give a distorted picture of any overall patterns. To protect against such an influence,

Table 9. Tug Fork at Litwar-regression analysis of relative trends in annual-flood peaks

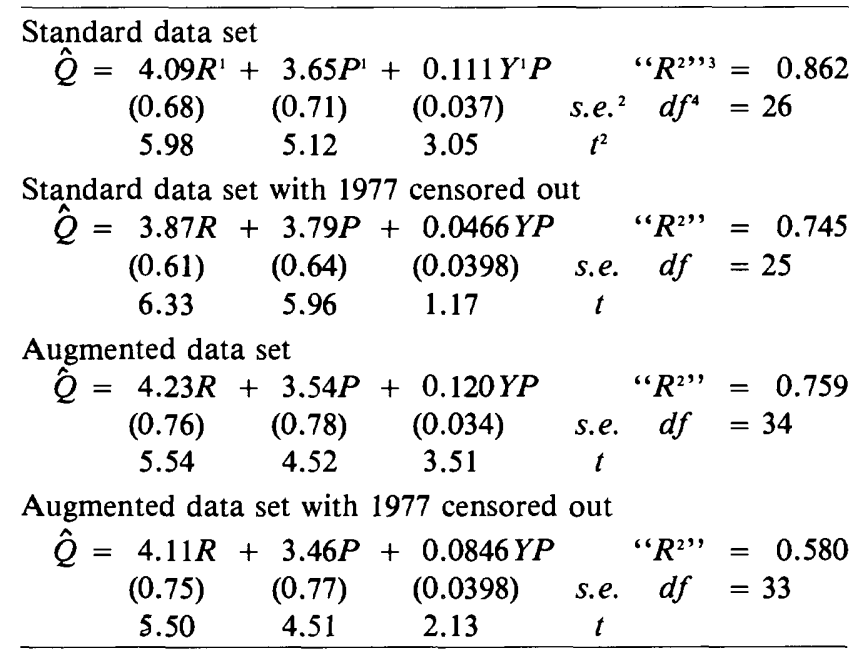

${ }^{1} \hat{Q}=$ predicted annual-flood peak at Litwar $\left(10^{3}\right.$ $\left.\mathrm{ft}^{\prime} / \mathrm{s}\right), \quad R^{\prime}=$ associated 2 -day maximum precipitation at Gary (inches), $P=$ associated flood peak at Panther $\left(10^{3} \mathrm{ft}^{3} / \mathrm{s}\right)$, and $Y=$ year of annual flood minus 1960 . In augmented data set: If precipitation data for Gary is missing, Hurley is used; if Panther discharge is missing, then regression relation between 2-day maximum precipitation at Hurley and Panther Creek peak discharge is used $\left(R^{2}=0.706\right)$.

${ }^{2}$ s.e. $=$ standard error of estimate for coefficients; $t=\mathrm{t}$ statistic for coefficients.

$$
{ }^{3} \text { " } R^{2} "=1-\frac{\sum(\hat{Q}-Q)^{2}}{\sum(Q-\bar{Q})^{2}} \text {, where } Q \text { is the actual flood peak }
$$

and $\bar{Q}$ is the average flood peak.

${ }^{4} d f=$ degrees of freedom (number of observations minus 3 ). 
regression analyses of relative trend in annual-flood peaks were performed by using all data except that for 1977. The results of these analyses are also presented in tables 9 and 10.

Table 9 gives results for Litwar. If the t-statistics for the regression coefficients exceed 2.0, the coefficients are significant at about the 5-percent level. The relative trend term YP-the product of the Panther Creek flood and the year index - has a significant coefficient in three of the four regression analyses. The only exception for Litwar occurs when 1977 is dropped from the standard data set. This indicates that the abnormally large 1977 flood does, in fact, have undue influence on the overall regression fit. The four regressions taken together, however, provide statistical evidence for an upwards trend in annual-flood peaks at Litwar relative to coincident flood peaks at Panther. They indicate that the factor by which one multiplies Panther Creek floods to get reasonable approximations of annual flood peaks at Litwar has increased since 1940.

Neither the analyses that treat 1977 the same as any other year nor the analyses that assume the 1977 data to be entirely lacking in useful information are wholly satisfactory. On the one hand, the 1977 data probably contain some useful information; on the other, there may be other abnormal years that distort the overall result. As an additional check on these results, the "robust regression" method of iterated weighted least squares (Mosteller and Tukey, 1977) also was used. This method uses a mechanical procedure to automatically assign weights to observations based on residuals of an initial regression fit. These weights may fall anywhere between zero and one. Observations with smaller residuals from the regression are given relatively larger weights. Weighted least squares are then run (Draper and Smith, 1966), and new weights computed. Refits using weighted least squares can be performed several times, depending on the choice of stopping rule or convergence criterion. We used the bisquare-weight function (Gross, 1977; Mosteller and Tukey, 1977), with starting weights computed from prediction residuals of an ordinary regression fit (Allen, 1971).

Results of the robust regressions for Litwar appear in the table 11. The trend coefficient in the robust regression using the augmented data set falls between the two ordinary regression trend coefficients but closer to the coefficient where 1977 is excluded. The trend coefficient is significant in both robust regressions.

Tables 10 and 11 contain the various robust regression results for annual-flood peaks at Kermit. The results are similar to those for Litwar. There is evidence for an upward relative trend compared to that of flood peaks at Panther. However, it again appears that the magnitude of the relative trend may be smaller than that indicated when the abnormal flood of 1977 is included in an ordinary regression analysis.

We can examine graphically the strength of the statistical evidence for upwards relative trends at Litwar and Kermit. Figures 16 and 17 are "adjusted variable plots" (Cleveland and others, 1981; Mosteller and Tukey, 1977) showing the relation of floods to the relative trend term after correcting for rainfall and Panther Creek floods. The vertical axis shows the residuals of floods after regressing on rainfall and Panther Creek floods. In effect, this is the remaining unexplained variation in floods before considering trend. The horizontal axis shows the residuals of the relative trend term after regressing it on rainfall and Panther Creek floods. This is the additional explanatory power of the relative trend term once all colinearity with rainfall and Panther Creek discharges has been removed. The slope of a simple regression fitted to these points is the coefficient of the relative trend term in the full multiple-regression equation.

The graphs reveal the trend patterns in annualflood peaks at Litwar and Kermit that result in the

Table 10. Tug Fork near Kermit-regression analysis of relative trends in annual-flood peaks

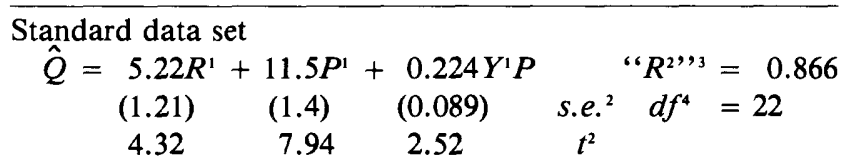

Standard data set with 1977 censored out

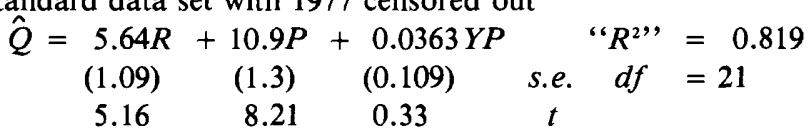

Augmented data set

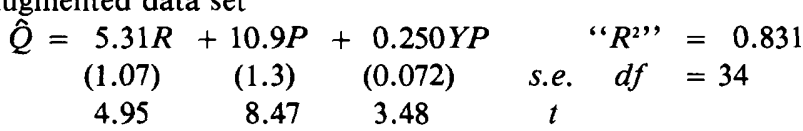

Augmented data set with 1977 censored out

$$
\begin{aligned}
& \hat{Q}=5.61 R+10.3 P+0.166 Y P \quad \text { " } R^{2} "=0.759 \\
& \begin{array}{llll}
(1.04) \quad(1.3) \quad(0.080) & \text { s.e. } d f=33
\end{array}
\end{aligned}
$$

$\begin{array}{llll}5.41 & 8.20 & 2.07\end{array}$

$1 \hat{Q}=$ predicted annual-flood peak at Kermit $\left(10^{3}\right.$ $\left.\mathrm{ft}^{3} / \mathrm{s}\right), R=$ associated 2-day maximum precipitation at Davella (inches), $P=$ associated flood peak at Panther $\left(10^{3} \mathrm{ft}^{3} / \mathrm{s}\right)$, and $Y=$ year of annual flood minus 1960 . In augmented data set: If precipitation data for Davella is missing, Pikeville is used; if neither Davella nor Pikeville precipitation data are available, Hurley is used; if Panther discharge is missing, then regression relation between 2-day maximum precipitation at Hurley and Panther Creek peak discharge is used $\left(R^{2}=0.706\right)$.

${ }^{2}$ s.e. $=$ standard error of estimate for coefficients; $t=t$ statistic for coefficients.

$$
\text { " " } R^{2} "=1-\frac{\sum(Q-\hat{Q})^{2}}{\Sigma(Q-\bar{Q})^{2}} \text {, where } Q \text { is the actual flood peak }
$$

and $\bar{Q}$ is the average flood peak.

${ }^{4} d f=$ degrees of freedom (number of observations minus 3 ). 
significant $t$-statistics for relative trend in the regression fits. But they also show that this statistical significance depends on just a few annual-flood peaks that are either very low in the 1940's or very high in the 1970's. In particular, the 1977 flood peaks-which appear as the extreme right-hand data points in both figures 16 and $17-$ lead to high regression coefficients. Thus, the significance of the relative trend term should be interpreted with caution.

Figures 18 and 19 show the practical significance, as opposed to statistical significance, of the regression fits. These figures show how expected annual-flood peaks at Litwar and Kermit have increased since 1940 for fixed rainfall and Panther Creek flood magnitudes. The confidence bands suggest the precision of the floodpeak estimates. These plots are based on the augmented data sets with 1977 data included. The rainfall and Panther Creek flood values used in these plots are those that actually occurred in 1974-78. For example, for the first graph of figure 19 (1974), the rainfall at Davella is 2.86 inches, and the Panther Creek flood is $1.79 \times 10^{3} \mathrm{ft}^{3} / \mathrm{s}$. Setting $Y$ to -20 (representing the year 1940), the estimated value of discharge at Kermit is $25.7 \times 10^{3} \mathrm{ft}^{3} / \mathrm{s}$. Setting $Y$ to +20 (representing the year 1980), the estimated value of discharge at Kermit is $43.6 \times 10^{3} \mathrm{ft}^{3} / \mathrm{s}$. The actual size of the 1974 flood was $53.0 \times 10^{3} \mathrm{ft}^{3} / \mathrm{s}$.

A final check on the validity of the regression results was made by examining residuals to check normality assumptions, both statistically (Shapiro and Wilk, 1965) and graphically (Daniel and Wood, 1971). No reason was found to reject the regression results for departure from normality assumptions.

To summarize the multiple-regression results, there is some statistical indication of upwards trend in

Table 11. Additional relative trend results for Litwar and Kermit from robust regression

[See tables 9 and 10 for definitions of variables]

Litwar standard data set

$$
\hat{Q}=\begin{array}{cccc}
3.75 R & 4.11 P \\
(0.68) & (0.71) & 0.113 Y P & \\
5.26 & 5.81 & (0.36) & \text { s.e. } \\
& &
\end{array}
$$

Litwar augmented data set

$$
\hat{Q}=\begin{array}{cccc}
4.17 R & 3.83 P \\
(0.85) & (0.87) & 0.0908 Y P & \\
4.93 & 4.41 & 2.039) & \text { s.e. } \\
& &
\end{array}
$$

Kermit standard data set

$$
\hat{Q}=\begin{array}{cccc}
4.87 R & 11.1 P- & 0.00384 Y P & \\
(0.71) & (0.86) & (0.052) & \text { s.e. } \\
6.83 & 13.0 & -0.07 & t
\end{array}
$$

Kermit augmented data set

$$
\hat{Q}=\begin{array}{clcc}
4.94 R & 10.9 P \\
(0.98) & (1.18) & 0.194 Y P & \\
5.02 & 9.21 & (0.065) & \text { s.e. } \\
& &
\end{array}
$$

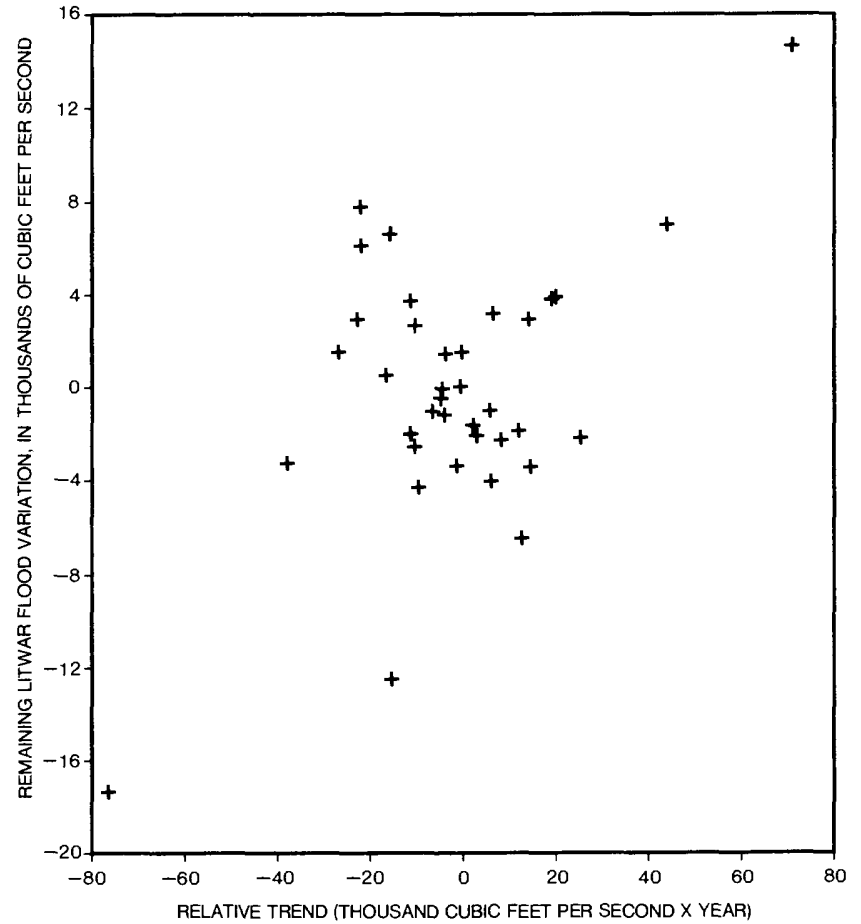

Figure 16. Adjusted variable plot for Tug Fork annual-flood peaks at Litwar, W. Va.

annual-flood-peak sizes at Litwar and Kermit that cannot, as yet, be explained. This seeming trend may be caused by chance variation in the data. The test statistic is never of overwhelming significance. When it is significant, it is caused by the influence of only two or three years of the flood record. In some model fits, the test statistic fails to attain significance at all. Also, this seeming trend could be explained by natural factors for which no data are available or it could be related to factors overlooked by the authors in their model formulation. Nonetheless, for the most complete data sets for Litwar and Kermit, statistical indication of a possible trend persists even when the abnormally large flood of 1977 is ignored. Thus, the possibility of an upward trend in annual-flood-peak sizes cannot be discarded based on presently available data and the analysis to date.

The relation of the possible upward trends in annual-flood peaks to surface mining is, as yet, undetermined. At present, surface-coal-production data for the Tug Fork basin upstream from the Litwar and Kermit gaging sites are available, but data on associated land disturbance are not (see table 5 and fig. 10). The best way to relate production in tons to extent of land disturbance is unclear. Tables 12 and 13 give some regression results by using three different coal production indexes for Litwar and Kermit: total coal production each year, total coal production each year and the two preceding 


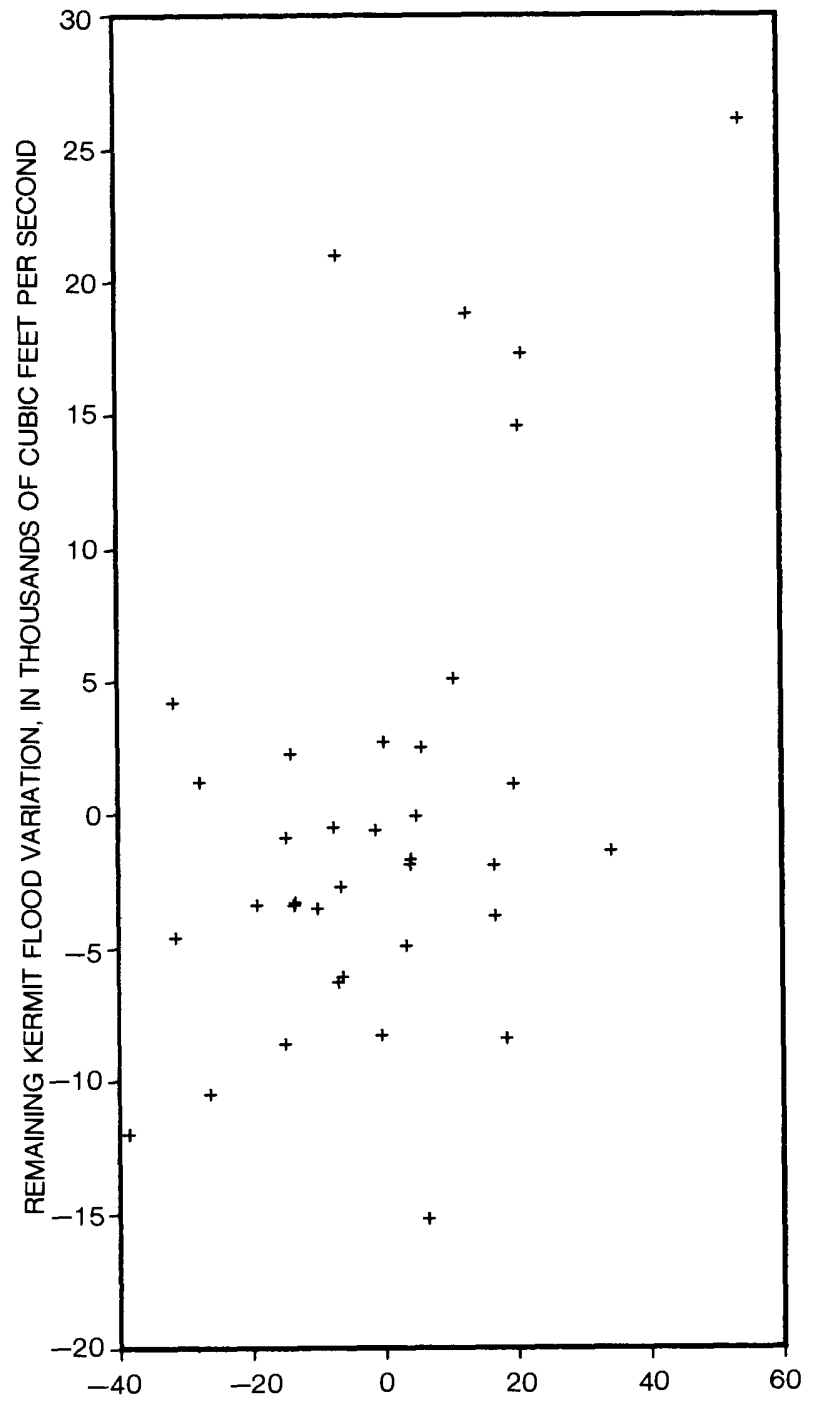

RELATIVE TREND (THOUSAND CUBIC FEET PER SECOND X YEAR)

Figure 17. Adjusted variable plot for Tug Fork annual-flood peaks near Kermit, W. Va.

years, and total coal production from each year back through 1940. Each coal production index is a possible measure of mining-related land disturbance. A relative trend term is formed by multiplying the Panther Creek flood levels by the given coal production index. Each regression analysis of relative trend answers the following question: If the size of annual-flood peaks on the Tug Fork is predicted by accounting for available rainfall information and then multiplying the Panther Creek flood by some factor, should this factor change for different values of the given coal-production index?

On the basis of the data presented in tables 12 and 13, the answer is yes-but for Litwar flood peaks and annual and three-year production indexes the answer is only tentative. (The t-statistics for trend in these cases are 1.37 and 1.85 , compared to the value of 2.0 needed for statistical significance at about the 5-percent level.) However, in no case does relating flood-peak trend to a coal production index give markedly better regression fits than simply relating flood-peak trends to year. Thus, though there is some indication of upward trends in annual-flood peaks on the Tug Fork relative to floods in the Panther Creek basin (where there is little surface mining), there is no additional evidence relating these trends to any specific coal-production index.

\section{CHANGES IN STREAM-CHANNEL SHAPE AND ALTITUDE}

An analysis was made to determine if the shape of the stream channels and (or) the altitude of the streambeds in the Tug Fork basin have changed significantly over time and, if so, whether the rates of these changes have increased or decreased during specific time periods.

As evidenced by our continually changing landscape, streams and rivers are dynamic systems. They are continually changing with time. Generally, changes such as deepening, widening, meander migration, and lateral movement of stream channels take place rather imperceptibly over long periods of time. The stream channel represents a composite of all the hydrologic and hydraulic factors acting on the surrounding soils. Such factors as flow quantity, stream gradient, cohesiveness of banks, type of bed material, and quantity of suspended sediment all influence the size and shape of stream channels. If a substantial change takes place in any one of these variables, the stream channel will adjust itself to accommodate the change.

To investigate whether any of these changes may have taken place at specific sites in the Tug Fork basin, data from the following three long-term gaging stations were used: 03213000 Tug Fork at Litwar, W. Va., 03213500 Panther Creek near Panther, W. Va., and 03214000 Tug Fork near Kermit, W. Va. The locations of these stations are shown in figure 5.

At each gaging station where records of flow are to be computed, a relation must be established between the altitude of the water surface (gage height) and the rate of flow (discharge). Discharge is normally measured in cubic feet per second, and gage height in feet. This relation (rating curve) is empirically determined for each gage site by measuring discharges at various gage heights, plotting these values on a graph, and drawing a smooth curve through the points. An example of a rating curve for station 03214000 Tug Fork near Kermit, W. Va., is shown in figure 20. As changes occur in the flow-carrying characteristics of the stream channel, they are reflected as changes in the gage height-discharge 

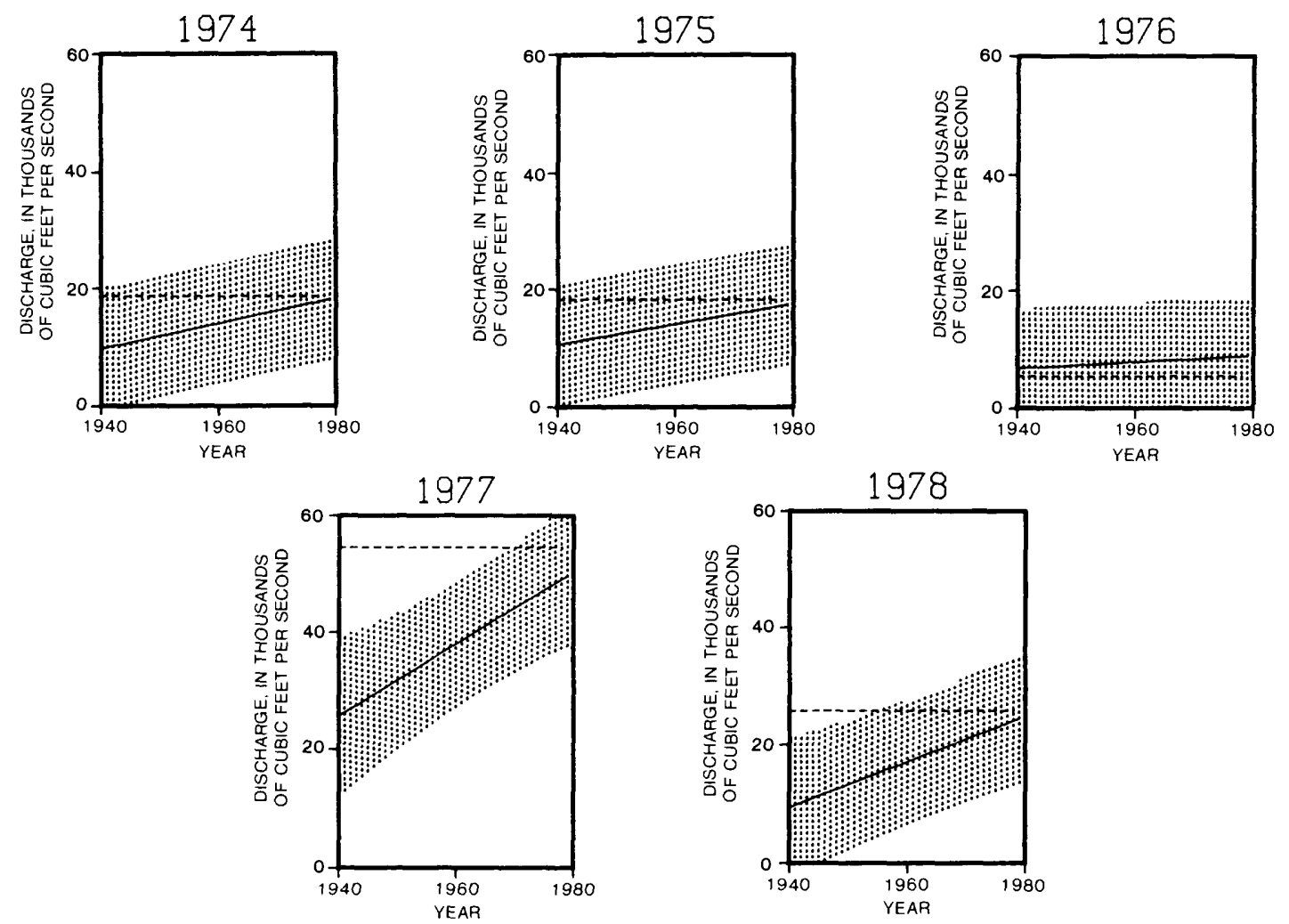

Figure 18. Estimated trend in Tug Fork annual-flood peaks at Litwar, W. Va., given 1974-78 meteorological conditions. The dashed lines show the actual 1974-78 annual-flood peaks near Litwar. The solid lines show regression model estimates of the flood that would have occurred each year, 1940-80, for the given meteorological conditions. The dotted area shows the 95-percent confidence intervals for the regression estimates.
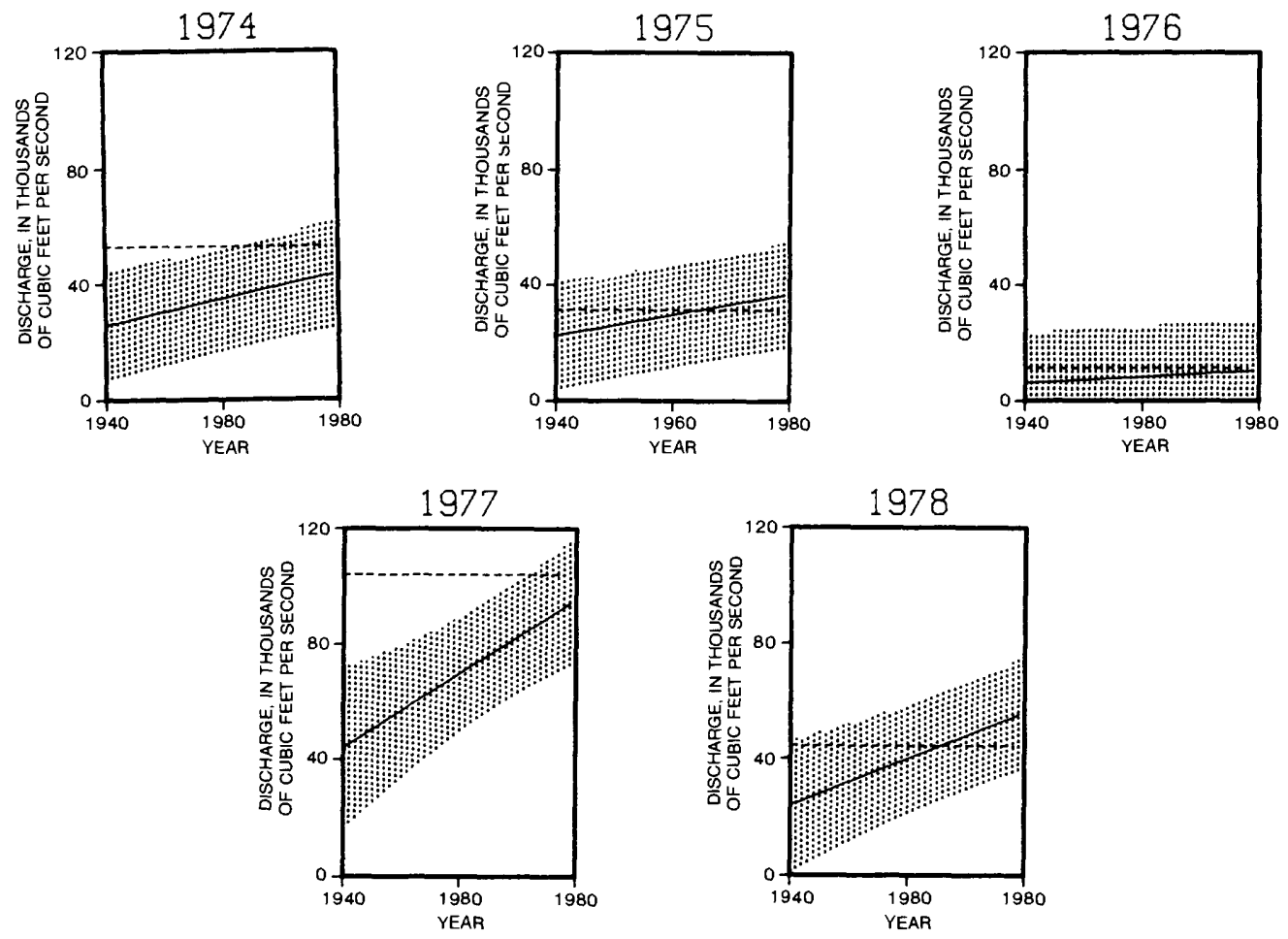

Figure 19. Estimated trend in Tug Fork annual-flood peaks near Kermit, W. Va., given 1974-78 meteorological conditions. The dashed lines show the actual 1974-78 annual-flood peaks near Kermit. The solid lines show regression model estimates of the flood that would have occurred each year, 1940-80, for the given meteorological conditions. The dotted area shows the 95-percent confidence intervals for the regression estimates. 
relation. This necessitates making periodic streamflow measurements to determine when changes have taken place and then redefining the rating as required.

The relation between gage height and discharge, for a specific gage site, is a function of such factors as channel width, channel depth, channel roughness, and streambed slope. Also, a rating curve is representative of only a single cross section or a single reach of river, referred to as the "control" for the gaging station.

The gage height for selected discharges was determined from all rating developed during the period of record for each of the three long-term gaging stations in the basin. These gage heights for selected discharges at each station were plotted against time and are shown in figures 21, 22, and 23. These gage heights and their period of use are listed in tables 14, 15, and 16 .

A general trend in aggradation or degradation of stream channels is not discernible from the graphs. Neither are general trends in changes in the flow-carrying characteristics of channels apparent. Changes that do occur at individual sites are scattered in time and do not indicate general trends for specific time periods.

When drawing inferences from these relations, one must remember that the accuracy of each may vary.

Table 12. Tug Fork at Litwar-regression analysis of trends in annual-flood peaks related to different coal production indexes (based on augmented data set)

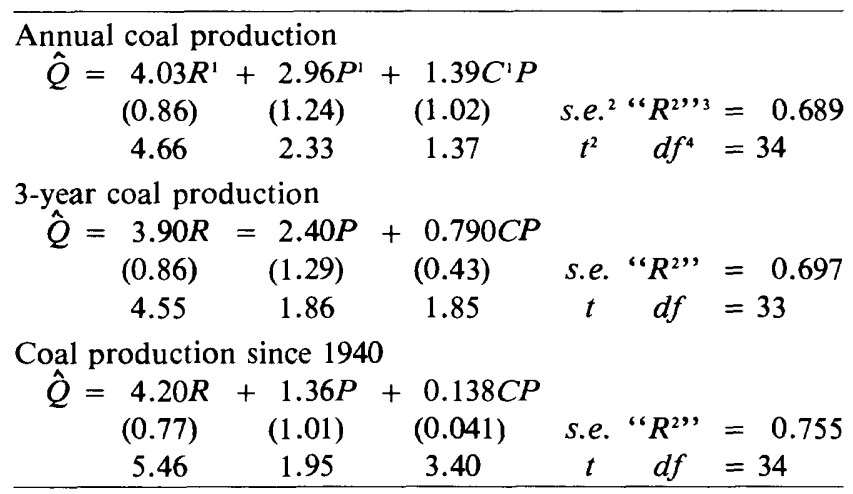

' $C=$ the given coal production index in millions of tons, $\hat{Q}=$ predicted annual-flood peak at Litwar $\left(10^{3} \mathrm{ft}^{3} / \mathrm{s}\right)$, $R=$ associated 2-day maximum precipitation at Gary (inches), $P=$ associated flood peak at Panther $\left(10^{3} \mathrm{ft}^{3} / \mathrm{s}\right)$, and $Y=$ year of annual flood minus 1960. If precipitation data for Gary is missing, Hurley is used; if Panther discharge is missing, then regression relation between 2-day maximum precipitation at Hurley and Panther Creek peak discharge is used $\left(R^{2}=0.706\right)$.

${ }^{2}$ s.e. = standard error of estimate for coefficients; $t=\mathrm{t}$ statistic for coefficients.

${ }^{3}$ " $R^{2} "=1-\frac{\sum(\hat{Q}-Q)^{2}}{\sum(Q-\bar{Q})^{2}}$, where $Q$ is the actual flood peak

and $\bar{Q}$ is the average flood peak.

$d f=$ degrees of freedom (number of observations minus 3 ).
Table 13. Tug Fork near Kermit-regression analysis of trends in annual-flood peaks related to different coal production indexes (based on augmented data set)

Annual coal production

$$
\begin{aligned}
& \hat{Q}=4.55 R^{1}+7.34 P^{1}+2.34 C^{1} P \\
& \text { (1.03) (2.01) (0.68) s.e. }{ }^{2} " R^{2}{ }^{2}{ }_{3}=0.841 \\
& \begin{array}{lllll}
4.41 & 3.66 & 3.43 & t^{2} \quad d f^{4}=33
\end{array}
\end{aligned}
$$

3-year coal production

$$
\begin{array}{ccccc}
\hat{Q}=4.78 R & =7.53 P & +0.766 C P & & \\
(1.03) & (1.87) & (0.207) & \text { s.e. " } R^{2} " & =0.844 \\
4.65 & 4.03 & 3.70 & t & d f=32
\end{array}
$$

Coal production since 1940

$$
\hat{Q}=\underset{(1.06)}{5.12 R}+\underset{(1.69)}{8.59 P}+\underset{(0.031)}{0.110 C P} \quad \text { s.e. " } R^{2} \text { " }=0.843
$$

$\begin{array}{lllll}4.84 & 5.10 & 3.53 & t & d f=33\end{array}$

${ }^{1} C=$ the given coal production index in millions of tons, $\hat{Q}=$ predicted annual-flood peak at Kermit $\left(10^{3} \mathrm{ft}^{3} / \mathrm{s}\right)$, $R=$ associated 2-day maximum precipitation at Davella (inches), $P=$ associated flood peak at Panther $\left(10^{3} \mathrm{ft}^{3} / \mathrm{s}\right)$, and $Y=$ year of annual flood minus 1960. If precipitation data for Davella is missing, Pikeville is used; if neither Davella nor Pikeville precipitation data are available, Hurley is used; if Panther discharge is missing, then regression relation between 2-day maximum precipitation at Hurley and Panther Creek peak discharge is used $\left(R^{2}=0.706\right)$.

${ }^{2}$ s.e. = standard error of estimate for coefficients; $t=\mathrm{t}$ statistic for coefficients.

${ }^{3}$ " $R^{2} "=1-\frac{\sum(\hat{Q}-Q)^{2}}{\sum(Q-\bar{Q})^{2}}$, where $Q$ is the actual flood peak and $\bar{Q}$ is the average flood peak.

${ }^{4} d f=$ degrees of freedom (number of observations minus 3 ).

The accuracy of the relations is a function of the accuracy of each discharge measurement and the number of discharge measurements used to define the gage height-discharge relation.

A discussion of the results for each individual station follows.

\section{Tug Fork at Litwar, West Virginia}

This station is located about 0.5 mile downstream from Litwar, W. Va. Drainage area above the station is 505 square miles. The present low-water control for the station is a natural rock riffle located about 500 feet downstream from the station. This station was located about 0.5 mile upstream before October 1942. The ratings for this station indicate a very uniform drop in gage height for a given discharge from 1930 to 1979 . This is true for both gage locations. From 1943 to 1979 , the gage heights fell about 1 foot. The water-surface elevation for high $\left(10,000 \mathrm{ft}^{3} / \mathrm{s}\right.$ or greater) discharges increased slightly. That is, for a discharge of $10,000 \mathrm{ft}^{3} / \mathrm{s}$ in 1944, the gage height would have been about 8.0 feet; in 1979 , it would have been about 8.3 feet. Because of 


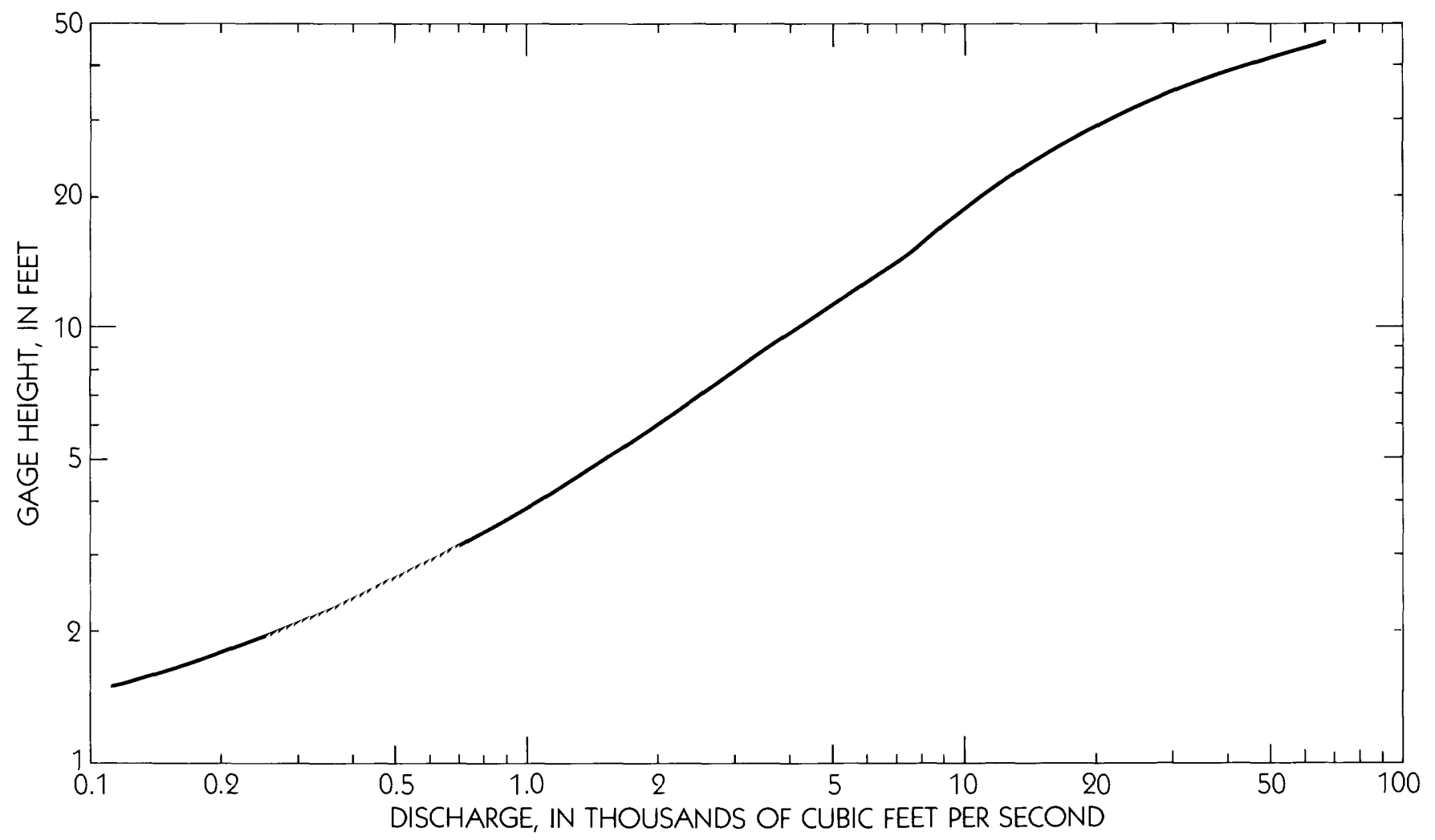

Figure 20. Rating curve for station 03214000 Tug Fork near Kermit, W. Va. (used December 31, 1962, to September 30, 1963).

the poor accuracy of high-flow measurements, an increase in gage height alone does not necessarily indicate any change in channel capacity. In fact, for flows up to $5,000 \mathrm{ft}^{3} / \mathrm{s}$, the channel capacity appears generally to have increased for a given gage height. This capacity increase appears to be so uniform in time that it is probably caused either by degradation or widening of the control section. The location of the control in a narrow, steeply banked channel indicated that degradation probably took place.

\section{Panther Creek near Panther, West Virginia}

This station is located in Panther State Forest about 3 miles southwest of Panther, W. Va. Drainage area above the station is 31.0 square miles and is almost undisturbed. Only about 0.3 square mile of area located in the headwaters of the basin has been disturbed by mining. The low-water control for this station was a rock outcrop located downstream from the gage until March 1963 when a large flood destroyed this outcrop and a rock riffle became the control. This control was effective until 1979 when a concrete weir was installed.
The ratings before and subsequent to the 1963 flood indicated no trends in the channel characteristics at this site.

\section{Tug Fork near Kermit, West Virginia}

This gaging station, located about 3 miles upstream from Kermit, W. Va., has a drainage area of 1,188 square miles. The gage is in a deep, narrow, heavily vegetated reach of the river. The low-water control for this station is a natural rock riffle, and the highwater control is the river channel.

The high-water rating characteristics at this site exhibited a significant change during the period of record. The gage height for flows larger than 10,000 $\mathrm{ft}^{3} / \mathrm{s}$ increased over 2 feet during the period of record. For example, the gage height for $20,000 \mathrm{ft}^{3} / \mathrm{s}$ was about 25.7 feet in 1950 and 28.4 feet in 1976. Most of the increase in gage height took place as a result of the February 1955 flood. The change could be due to sloughing of banks, deposition of sediment on flood plains, or build up of debris or vegetation downstream. However, the exact cause is not known. 


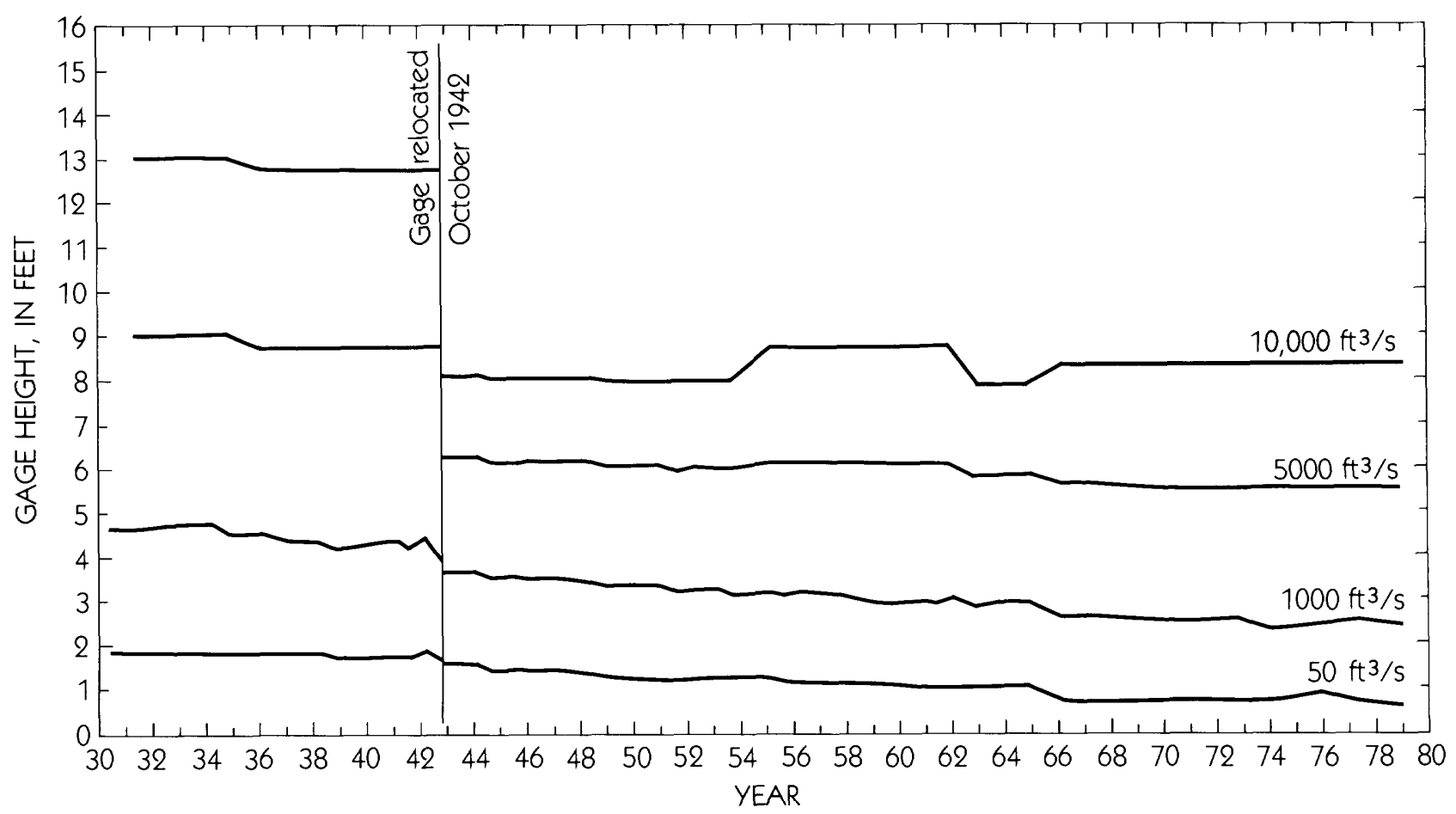

Figure 21. Changes in gage height with time for selected discharges at station 03213000 Tug Fork at Litwar, W. Va.

Channel cross sections obtained at various times are shown in figure 24 . These cross sections were obtained from discharge measurements made from a cableway located about 0.5 mile downstream from the station and indicate no significant reduction in channel area at this site.

The low-water control evidently degraded slightly during the period of record. At a discharge $50 \mathrm{ft}^{3} / \mathrm{s}$, this degradation resulted in a drop in gage height of about 0.2 foot during the period.

\section{SUMMARY}

Historical streamflow data from three gaging stations in the Tug Fork basin of Kentucky, Virginia, and West Virginia were analyzed to determine if changes or trends in flooding characteristics have occurred. Streamflow data from the following stations were utilized: 03213000 Tug Fork at Litwar, W. Va., 03213500 Panther Creek near Panther, W. Va., and 03214000 Tug Fork near Kermit, W. Va.
Initial analyses consisted of applying the MannKendall test for trends to the annual-flood data and comparing box plots of these data. These analyses indicated that there has been an upward trend in the flood-frequency distributions at all three sites. It should be noted that Panther Creek basin contains almost no surface disturbance due to mining.

Analyses then were made to determine if trends existed in the number of times each year that floods exceeded certain base flows at the three sites. Analyses were made graphically by utilizing box plots of exceedance frequencies and were made mathematically by computing log-likelihood ratios. These analyses provided no strong evidence of a trend in any of these partial-duration series. There were, however, weak indications of a possible upwards trend in frequency of larger floods at Litwar and Kermit. Analysis of the annual-flood-producing rainfall did not reveal any trends.

The third series of analyses utilized multiple regression to investigate possible causes of changes- 


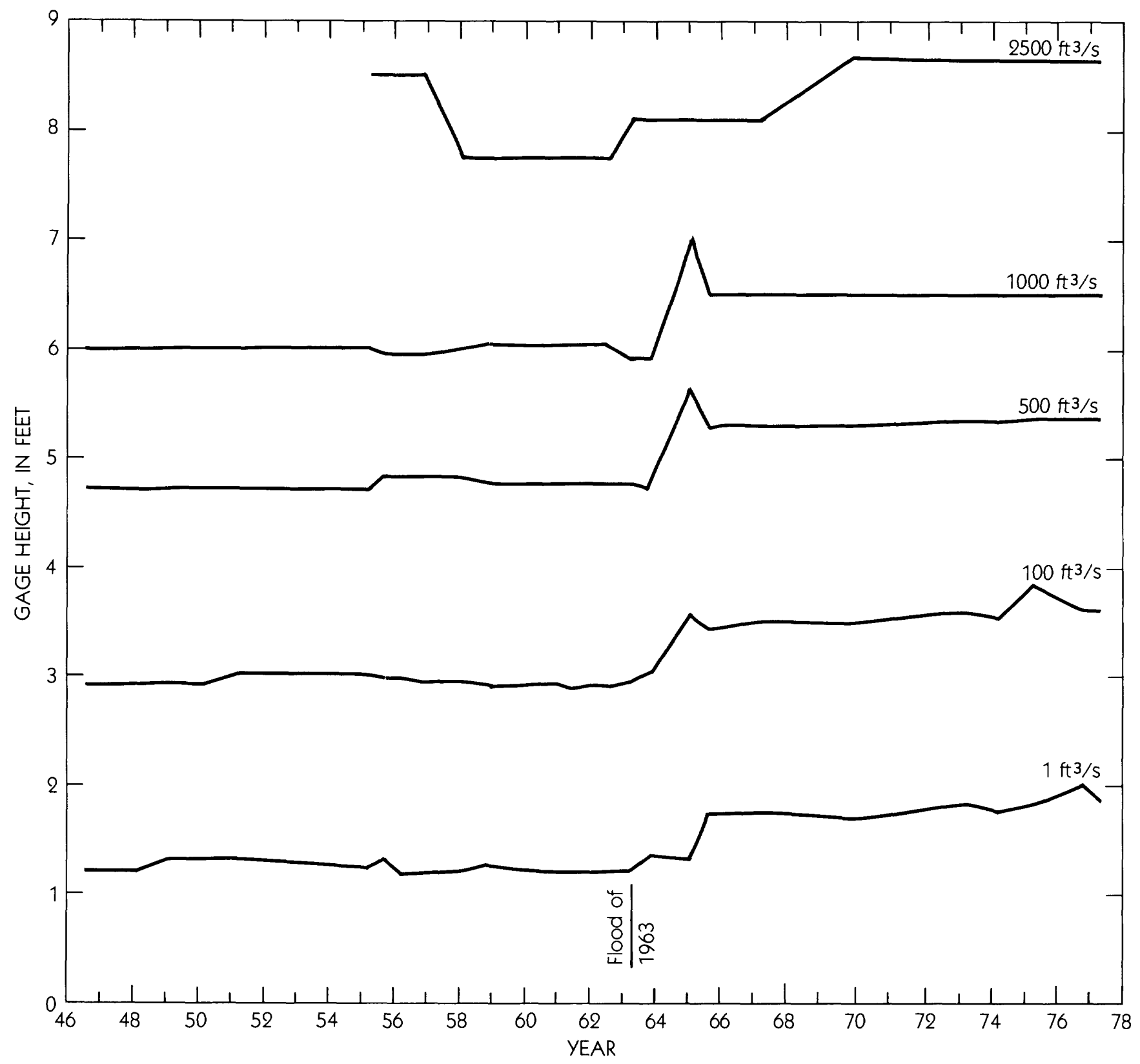

Figure 22. Changes in gage height with time for selected discharges at station 03213500 Panther Creek near Panther, W. Va.

meteorological changes or changes in the hydrologic response. Floods at Kermit and Litwar were statistically related to rainfall and a factor times the flood at Panther. This factor was investigated to determine whether it changed with time. There was some statistical indication that it did change, but the evidence was not overwhelming, based on available data.
An analysis also was made of existing data to determine if the flow-carrying capacity of the stream channel had significantly changed with time at the three sites. Some changes that had taken place were attributable to specific high-flow events, and no general trend could be identified. Detailed land-use and land-cover data were not available for these analyses. 


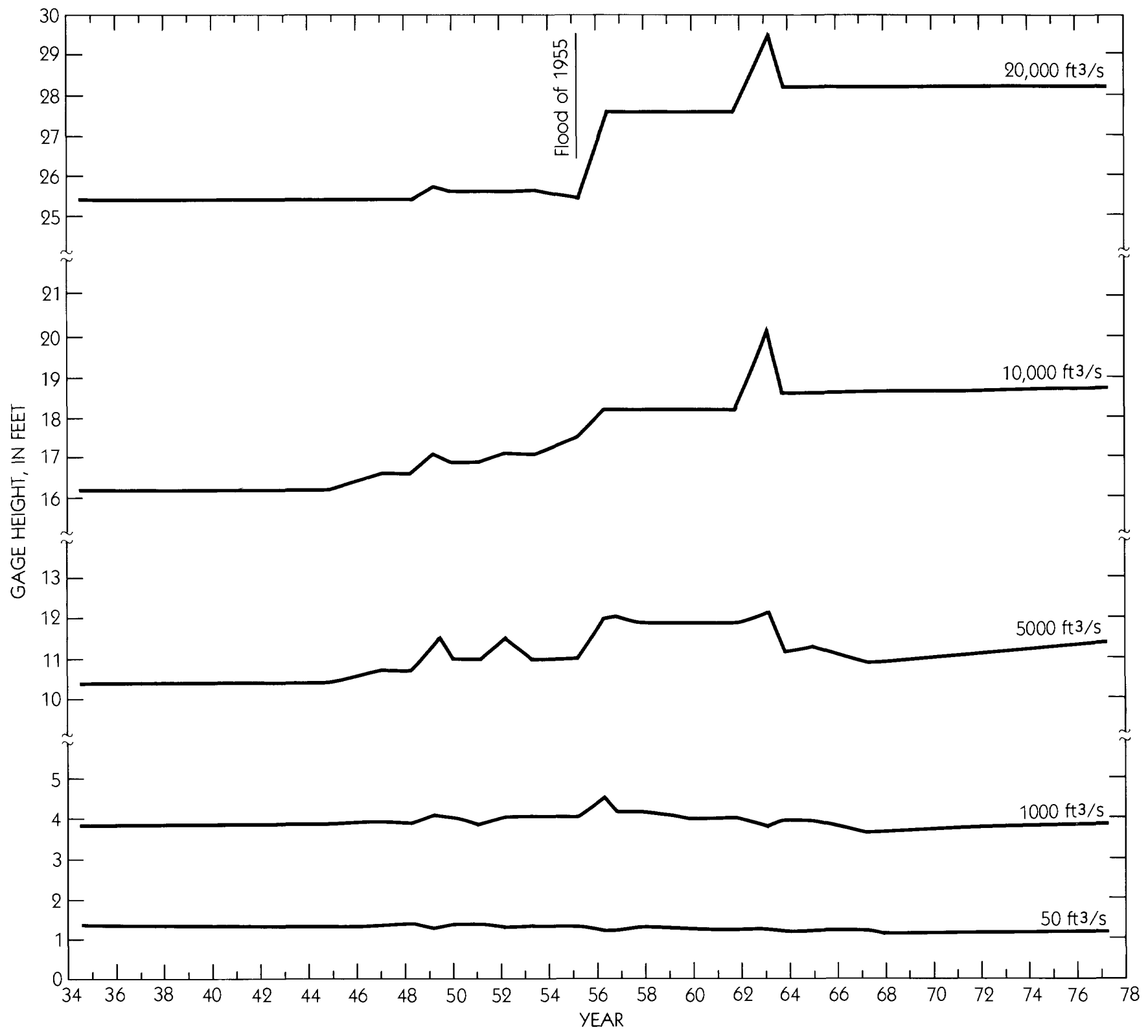

Figure 23. Changes in gage height with time for selected discharges at station 03214000 Tug Fork near Kermit, W. Va. 
Table 14. Gage height for selected discharges at gaging station 03213000 Tug Fork at Litwar, W. Va.

\begin{tabular}{|c|c|c|c|c|}
\hline \multirow[t]{2}{*}{$\begin{array}{l}\text { Period of } \\
\text { rating use }\end{array}$} & \multirow[b]{2}{*}{$50 \mathrm{ft}^{3 / \mathrm{s}}$} & \multicolumn{2}{|c|}{ Gage height in feet for indicated discharges } & \multirow[b]{2}{*}{$10,000 \mathrm{ft}^{3} / \mathrm{s}$} \\
\hline & & $1,000 \mathrm{ft}^{3} / \mathrm{s}$ & $5,000 \mathrm{ft}^{3} / \mathrm{s}$ & \\
\hline $5 / 30--1 / 31$ & 1.83 & 4.63 & & \\
\hline $4 / 31---9 / 32$ & 1.84 & 4.75 & 9.06 & 13.00 \\
\hline $9 / 32--3 / 34$ & $1-$ & - & - & - \\
\hline 3/34 - & 1.80 & 4.57 & - & - \\
\hline 2/37 - & 1.80 & 4.20 & - & - \\
\hline $3 / 38--4 / 38$ & - & 4.31 & - & - \\
\hline 4/38 - & 1.73 & 4.20 & - & - \\
\hline $11 / 38$-- & 1.72 & 4.32 & - & - \\
\hline $9 / 40----3 / 41$ & 1.73 & 4.35 & - & - \\
\hline $10 / 42-\cdots-12 / 42$ & & 3.65 & 6.23 & 8.10 \\
\hline 12/42 ------9/42 & 1.53 & - & - & - \\
\hline $9 / 43-2 / 44$ & 1.57 & - & - & - \\
\hline 2/44 -----1/44 & 1.48 & 3.55 & 6.19 & 8.03 \\
\hline 9/44 --_---1/45 & - & - & - & - \\
\hline 9/45 --------1/46 & 1.47 & 3.50 & - & - \\
\hline $1 / 46-1 / 47$ & 1.45 & - & - & - \\
\hline $1 / 47---------2 / 48$ & 1.40 & 3.46 & 6.17 & - \\
\hline 2/48 ----1/49 & 1.31 & 3.36 & 6.09 & 8.00 \\
\hline $1 / 49-12 / 50$ & 1.23 & 3.32 & - & - \\
\hline $12 / 57-1 / 59$ & 1.11 & 2.98 & - & - \\
\hline $1 / 59---9 / 59$ & 1.08 & 2.95 & 6.10 & - \\
\hline $9 / 59$ & - & 2.97 & - & - \\
\hline $12 / 60------5 / 61$ & 1.02 & - & 6.12 & - \\
\hline $5 / 61+12 / 61$ & - & 3.02 & - & - \\
\hline 12/61 ----11/62 & - & 2.88 & 5.81 & 7.90 \\
\hline $11 / 62-9 / 63$ & 1.07 & 2.93 & 5.85 & - \\
\hline 9/63 - 11/64 & - & - & - & - \\
\hline $11 / 64-2 / 66$ & 0.78 & 2.65 & 5.69 & 8.37 \\
\hline 2/66 -------9/66 & - & 2.63 & - & - \\
\hline 9/66 - & 0.73 & 2.51 & 5.53 & - \\
\hline $10 / 70-----8 / 72$ & 0.77 & 2.58 & - & - \\
\hline 8/72 ----- $4 / 73$ & 0.73 & 2.48 & - & - \\
\hline 4/73 - & - & 2.35 & - & - \\
\hline 3/74 - & 0.90 & 2.45 & - & - \\
\hline $12 / 75------4 / 77$ & 0.73 & 2.54 & - & - \\
\hline 4/77 -- & 0.63 & 2.43 & - & - \\
\hline
\end{tabular}

' Dash in column indicates no change from previous value. 
Table 15. Gage height for selected discharges at gaging station 03214000 Tug Fork near Kermit, W. Va.

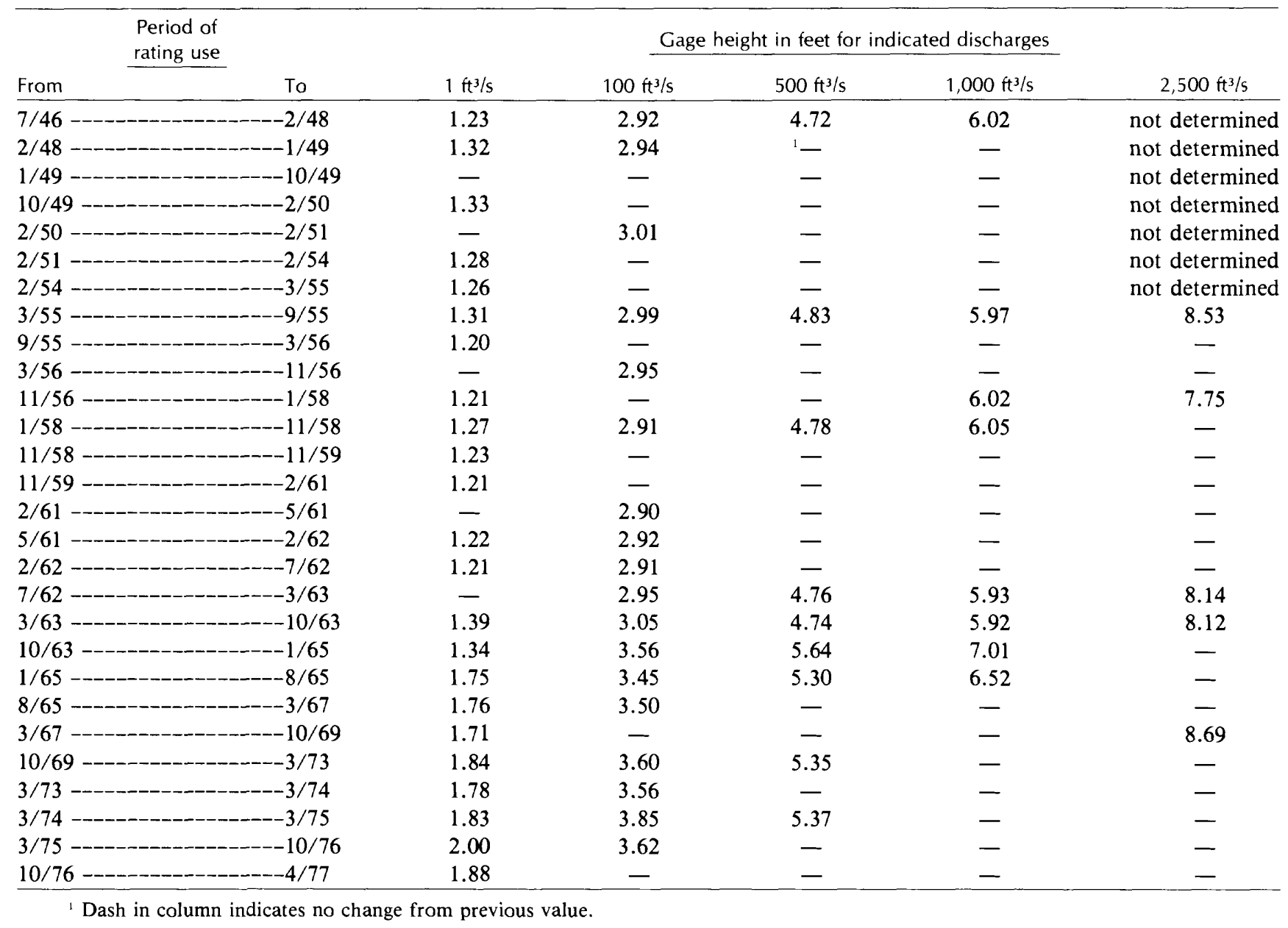

\section{REFERENCES}

Akaike, H., 1970, Information theory and an extension of the maximum likelihood principle, in Petrou, B. N., and Csaki, F., eds., 2nd International Symposium on Information Theory: Akademiai Kiado, Budapest, Hungary, p. 267-281.

Allen, D. M., 1971, Mean square error of prediction as a criterion for selecting variables: Technometrics, v. 13, no. 3 , p. $469-475$.

Anderson, J. R., Hardy, E. E., Roach, J. T., and Witmer, R. E., 1976, A land use and land cover classification system for use with remote sensor data: U.S. Geological Survey Professional Paper 964, 28 p.

Anderson, O. K., 1959, Climates of the States, Kentucky: U.S. Department of Commerce, Climatography of the United States No. 60-15, 15 p.

Bradley, J. V., 1968, Distribution free statistical tests: Englewood Cliffs, N.J., Prentice-Hall, 388 p.

Brown, R. L., Durbin, J., and Evans, J. M., 1975, Techniques for testing the constancy of regression relationships over time: Journal of the Royal Statistical Society B, v. 2, p. 149-163.
Bryan, B. A., and Hewlett, J. D., 1981, Effect of surface mining on storm flow and peak flow from six small basins in Eastern Kentucky: Water Resources Bulletin, AWRA, v. 17, no. 2, p. 290-299.

Cleveland, W. S., Chambers, J. M., Kleincs, B., and Tukey, P. A., 1981, Graphical methods for data analysis, unpublished manuscript.

Crockett, C. W., 1971, Climates of the States, Virginia: U.S. Department of Commerce, Climatography of the United States No. 60-44, 25 p.

Crowe-Carraco, Carol, 1979, The Big Sandy: Lexington, Ky., University Press of Kentucky, 136 p.

Daniel, C., and Wood, F. S., 1971, Fitting equations to data: New York, John Wiley, 402 p.

Draper, N. R., and Smith, H., 1966, Applied regression analysis: New York, John Wiley, 407 p.

Edwards, A. W. F., 1972, Likelihood: London, United Kingdom, Cambridge University Press, 235 p.

Fenneman, N. M., 1946, Physical divisions of the United States: U.S. Geological Survey miscellaneous map, scale $1: 7,000,000$.

Gross, A. M., 1977, Confidence intervals for bisquare regression estimates: Journal of the American Statistical Association, v. 72 , p. 341-354. 
Table 16. Gage height for selected discharges at gaging station 03213500 Panther Creek near Panther, W. Va.

\begin{tabular}{|c|c|c|c|c|c|}
\hline \multirow[t]{2}{*}{$\begin{array}{l}\text { Period of } \\
\text { rating use }\end{array}$} & \multirow[b]{2}{*}{$50 \mathrm{ft}^{3 / \mathrm{s}}$} & \multirow[b]{2}{*}{$1,000 \mathrm{ft}^{3} / \mathrm{s}$} & \multicolumn{2}{|c|}{ Gage height in feet for indicated discharges } & \multirow[b]{2}{*}{$20,000 \mathrm{ft}^{3 / \mathrm{s}}$} \\
\hline & & & $5,000 \mathrm{ft}^{3} / \mathrm{s}$ & $10,000 \mathrm{ft}^{3 / 5}$ & \\
\hline 7/34---- 10/44 & 1.35 & 3.85 & 10.4 & 16.2 & 25.4 \\
\hline $10 / 44-\cdots--1 / 47$ & '- & 3.93 & 10.7 & 16.6 & - \\
\hline $1 / 47----------4 / 48$ & 1.39 & - & - & - & - \\
\hline 4/48--_-----3/49 & 1.33 & 4.07 & 11.5 & 17.1 & 25.7 \\
\hline $3 / 49--12 / 49$ & 1.39 & 4.03 & 11.0 & 16.9 & 25.6 \\
\hline $12 / 49-------2 / 51$ & - & 3.88 & - & - & - \\
\hline $2 / 51-------3 / 52$ & 1.31 & 4.03 & 11.5 & 17.1 & - \\
\hline $3 / 52---------5 / 53$ & 1.32 & - & - & - & - \\
\hline $5 / 53--------3 / 55$ & - & - & 11.0 & 17.5 & 25.4 \\
\hline $3 / 55 \cdots-4 / 56$ & 1.26 & 4.50 & 12.0 & 18.2 & 27.6 \\
\hline $4 / 56-10 / 56$ & - & 4.17 & - & - & - \\
\hline $10 / 56-----10 / 57$ & 1.30 & 4.15 & 11.9 & - & - \\
\hline $10 / 57--------5 / 58$ & - & 4.10 & - & - & - \\
\hline $5 / 58+-1 / 59$ & - & - & - & - & - \\
\hline $1 / 59--10 / 59$ & 1.26 & 4.00 & - & - & - \\
\hline $11 / 59-----10 / 61$ & - & - & 11.8 & - & - \\
\hline $10 / 61----12 / 62$ & - & 3.83 & 12.1 & 20.1 & 29.5 \\
\hline $12 / 62-------10 / 63$ & 1.22 & 3.93 & 11.2 & 18.6 & 28.2 \\
\hline $10 / 63-----2 / 65$ & 1.21 & 3.90 & 11.3 & - & - \\
\hline 2/65------3/67 & - & 3.67 & 10.9 & - & - \\
\hline $3 / 67-------11 / 67$ & 1.15 & - & - & - & - \\
\hline $12 / 69------4 / 77$ & 1.19 & 3.85 & 11.4 & 18.7 & - \\
\hline
\end{tabular}

' Dash in column indicates no change from previous value.

Hocking, R. R., 1976, The analysis and selection of variables in linear regression: Biometrics, v. 32, p. 1-50.

Horn, V. T., and McGuire, J. K., 1960, Climates of the States, West Virginia: U.S. Department of Commerce, Climatography of the United States No. 60-46, 15 p.

Johnson, N. L., and Kotz, Samuel, 1969, Discrete distributions: Boston, Houghton Mifflin Co., 227 p.

Kendall, M. G., 1975, Rank correlation methods: London, United Kingdom, Charles Griffin and Company, Ltd., 202 p.

Kendall, M. G., and Stuart, Alan, 1973, The advanced theory of statistics, Vol. 2: London, United Kingdom, Charles Griffin, 723 p.

Kleiner, B., and Graedel, T. E., 1980, Exploratory data analysis in the geophysical sciences: Reviews of Geophysics and Space Physics, v. 18, no. 3, p. 699-717.

Mosteller, F., and Tukey, J. W., 1977, Data analysis and regression: Reading, Mass., Addison-Wesley, 588 p.

National Oceanic and Atmospheric Administration, 1973, Monthly normals of temperature, precipitation, and heating and cooling degree days 1941-70: Climatography of the United States No. 81 (Virginia, West Virginia, and Kentucky), 7 p.

Runner, G. S., 1979, Flood of April 1977 on the Tug Fork, Matewan to Williamson, West Virginia and Kentucky: U.S. Geological Survey Hydrologic Investigations Atlas 588 .
Runner, G. S., and Chin, E. H., 1980, Flood of April 1977 in the Appalachian region of Kentucky, Tennessee, Virginia, and West Virginia: U.S. Geological Survey Professional Paper 1098, 43 p.

Scott, A. G., 1980, Interim report on the investigation of flooding in the Tug Fork basin of Kentucky, Virginia, and West Virginia: U.S. Geological Survey Water-Resources Inv. 80-1188, $116 \mathrm{p}$.

Shane, R. M., and Lynn, W. R., 1964, Mathematical model for flood risk evaluation: American Society of Civil Engineers, Journal of the Hydraulics Division, v. 90, no. Hy6, p. 1-20.

Shapiro, S. S., and Wilk, M. B., 1965, An analysis of variance test for normality (complete samples): Biometrika, p. 591-611.

Snedecor, G. W., and Cochran, W. G., 1967, Statistical methods: Ames, Iowa State University Press, 593 p.

Tug Valley Recovery Center, 1978, A clear and imminent danger: The case for designating the Tug Fork watershed unsuitable for strip mining: Williamson, W. Va., The Tug Valley Recovery Center, Inc., $50 \mathrm{p}$.

U.S. Army Corps of Engineers, 1979, Baseline report on the existing environment of the Tug Fork River basin: Huntington District, W. Va., 54 p.

U.S. Geological Survey, 1970, The national atlas of the United States: U.S. Geological Survey, 417 p. 


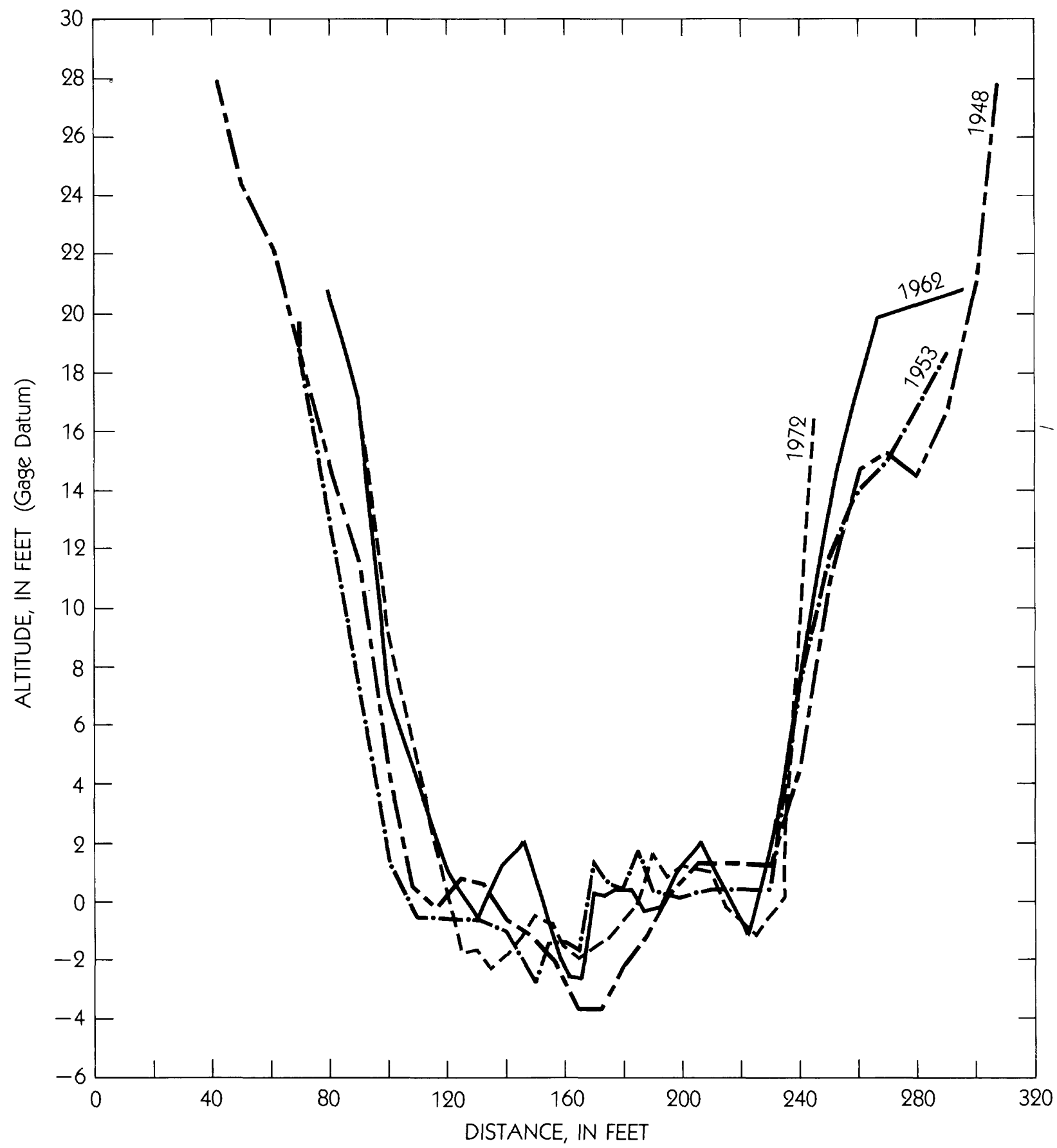

Figure 24. Cross sections of stream channel at station 03214000 Tug Fork at Kermit, W. Va.

1976, Land use and land cover, 1973 and 1975, Huntington, West Virginia-Kentucky-Ohio: Open-File Report 76-37, scale 1:250,000.

1978a, Land use and land cover, 1976, Jenkins, Kentucky-Virginia-West Virginia: Open-File Report 78-278, scale $1: 250,000$.

1978b, Land use and land cover, 1973-76, Bluefield, West Virginia-Virginia-Kentucky: Open-File Report $78-415$, scale $1: 250,000$.
Annual Series, 1961-present, Water Resources Data for Kentucky, U.S. Geological Survey Water-Data Report , Water Resources Division, Louisville, Ky.

Annual Series, 1961-present, Water Resources Data for Virginia, U.S. Geological Survey Water-Data Report , Water Resources Division, Richmond, Va.

Annual Series, 1961-present, Water Resources Data for West Virginia, U.S. Geological Survey Water-Data Report _ Water Resources Division, Charleston, W. Va. 
Metric Conversion Factors

\begin{tabular}{|c|c|c|}
\hline Multiply & By & To obtain SI metric units \\
\hline \multicolumn{3}{|c|}{ Length } \\
\hline inch (in.) & $2.54 \times 10^{1}$ & millimeter $(\mathrm{mm})$ \\
\hline & $2.54 \times 10^{-2}$ & meter $(\mathrm{m})$ \\
\hline foot $(\mathrm{ft})$ & $3.048 \times 10^{-1}$ & meter $(\mathrm{m})$ \\
\hline & $1.609 \times 10^{\circ}$ & kilometer $(\mathrm{km})$ \\
\hline \multicolumn{3}{|c|}{ Area } \\
\hline acre & $4.047 \times 10^{3}$ & square meter $\left(\mathrm{m}^{2}\right)$ \\
\hline & $4.047 \times 10^{-1}$ & square hectometer $\left(\mathrm{hm}^{2}\right)$ \\
\hline & $4.047 \times 10^{-3}$ & square kilometer $\left(\mathrm{km}^{2}\right)$ \\
\hline square mile $\left(\mathrm{mi}^{2}\right)$ & $2.590 \times 10^{0}$ & square kilometer $\left(\mathrm{km}^{2}\right)$ \\
\hline \multicolumn{3}{|c|}{ Flow } \\
\hline cubic foot per second $\left(\mathrm{ft}^{3} / \mathrm{s}\right)$ & $2.832 \times 10^{1}$ & liter per second $(\mathrm{L} / \mathrm{s})$ \\
\hline & $2.832 \times 10^{1}$ & cubic decimeter per second $\left(\mathrm{dm}^{3} / \mathrm{s}\right)$ \\
\hline & $2.832 \times 10^{-2}$ & cubic meter per second $\left(\mathrm{m}^{3} / \mathrm{s}\right)$ \\
\hline \multicolumn{3}{|c|}{ Mass } \\
\hline ton (short) & $9.072 \times 10^{-1}$ & megagram $(\mathrm{Mg})$ or metric ton \\
\hline
\end{tabular}




\section{APPENDIX A: DATA SET FOR TUG FORK AT LITWAR, WEST VIRGINIA}

The years are water years. $Q$ is the annual-flood peak at the Litwar gage, $R$ is the associated maximum 2-day rainfall at Gary, W. Va., P is the associated flood peak at the Panther Creek near Panther, W. Va., gage. KCFS is thousands of cubic feet per second.

$\begin{array}{lrccc} & \text { Q } & \text { R } & \text { P } & \\ \text { year } & \text { KCFS } & \begin{array}{c}\text { in } \\ \text { inches }\end{array} & \begin{array}{c}\text { in } \\ \text { KCFS }\end{array} & \text { date } \\ & & & & \\ 1941 & 7.31 & 0.90 & -- & 03 / 11 \\ 1942 & 5.49 & 2.08 & -- & 06 / 20 \\ 1943 & 14.00 & 1.86 & -- & 03 / 13 \\ 1944 & 15.80 & 1.90 & -- & 02 / 18 \\ & & & & \\ 1945 & 19.40 & 1.96 & -- & 02 / 17 \\ 1946 & 19.80 & 2.76 & -- & 01 / 07 \\ 1947 & 7.93 & 1.68 & 0.576 & 01 / 16 \\ 1948 & 12.90 & 1.08 & 1.700 & 02 / 13 \\ 1949 & 8.93 & 2.38 & 0.927 & 12 / 04 \\ & & & & \\ 1950 & 20.50 & 2.08 & 1.350 & 02 / 02 \\ 1951 & 6.72 & 1.10 & -- & 12 / 08 \\ 1952 & 12.70 & 2.42 & 1.260 & 04 / 28 \\ 1953 & 16.50 & 2.17 & 1.260 & 05 / 19 \\ 1954 & 14.20 & 4.36 & -- & 07 / 21 \\ & & & & \\ 1955 & 23.00 & 2.22 & 4.200 & 03 / 06 \\ 1956 & 13.50 & 2.32 & 1.670 & 04 / 16 \\ 1957 & 35.70 & -- & 3.600 & 01 / 29 \\ 1958 & 16.10 & 2.35 & 1.280 & 08 / 25 \\ 1959 & 8.70 & 1.10 & 1.180 & 04 / 12 \\ & & & & \\ 1960 & 4.66 & 1.22 & 0.798 & 11 / 28 \\ 1961 & 8.90 & 0.74 & 1.460 & 02 / 25 \\ 1962 & 10.20 & 1.39 & 1.120 & 02 / 28 \\ 1963 & 28.30 & 2.66 & 4.570 & 03 / 12 \\ 1964 & 7.58 & 1.47 & 0.836 & 03 / 09 \\ 1965 & 16.30 & 2.78 & 1.510 & 03 / 26 \\ 1966 & 8.96 & 2.20 & 1.050 & 05 / 02 \\ 1967 & 20.70 & 2.04 & 4.600 & 03 / 07 \\ 1968 & 13.80 & 1.56 & 1.060 & 05 / 27 \\ 1969 & 2.23 & 0.78 & 0.308 & 01 / 21 \\ 1970 & 11.50 & 1.49 & 1.820 & 02 / 16 \\ 1975 & 18.20 & 2.11 & 1.450 & 03 / 14 \\ 1971 & 13.50 & 2.75 & 1.480 & 05 / 07 \\ 1972 & 17.30 & 2.22 & 1.340 & 01 / 21 \\ 1973 & 18.70 & 2.64 & 2.510 & 03 / 17 \\ 1974 & 18.60 & 1.81 & 1.790 & 01 / 11 \\ & 54.50 & 4.66 & 5.140 & 04 / 04 \\ & 25.80 & 1.36 & 3.210 & 01 / 26 \\ & 13.80 & -- & 1.160 & 01 / 21\end{array}$




\section{APPENDIX B: AUGMENTED DATA SET FOR TUG FORK AT LITWAR, WEST VIRGINIA}

The years are water years. $Q$ is the annual-flood peak at the Litwar gage, $R$ is the associated maximum 2-day rainfall at Gary, W. Va. If the Gary value is missing, the Hurley, Va., rainfall is used. P is the associated flood peak at the Panther Creek near Panther, W. Va., gage. If it is missing, it is estimated from the regression relation of 2-day maximum precipitation at Hurley, W. Va., and Panther Creek peak discharge. KCFS is thousands of cubic feet per second.

\begin{tabular}{|c|c|c|c|c|}
\hline & $\begin{array}{l}Q \\
\text { in }\end{array}$ & $\begin{array}{l}\mathrm{R} \\
\text { in }\end{array}$ & $\begin{array}{l}P \\
\text { in }\end{array}$ & \\
\hline year & KCFS & inches & KCFS & date \\
\hline 1941 & 7.31 & 0.90 & 0.770 & $03 / 11$ \\
\hline 1942 & 5.49 & 2.08 & 3.497 & $06 / 20$ \\
\hline 1943 & 14.00 & 1.86 & 0.704 & $03 / 13$ \\
\hline 1944 & 15.80 & 1.90 & 1.281 & $02 / 18$ \\
\hline 1945 & 19.40 & 1.96 & 1.307 & $02 / 17$ \\
\hline 1946 & 19.80 & 2.76 & - & $01 / 07$ \\
\hline 1947 & 7.93 & 1.68 & 0.576 & $01 / 16$ \\
\hline 1948 & 12.90 & 1.08 & 1.700 & $02 / 13$ \\
\hline 1949 & 8.93 & 2.38 & 0.927 & $12 / 04$ \\
\hline 1950 & 20.50 & 2.08 & 1.350 & $02 / 02$ \\
\hline 1951 & 6.72 & 1.10 & 0.206 & $12 / 08$ \\
\hline 1952 & 12.70 & 2.42 & 1.260 & $04 / 28$ \\
\hline 1953 & 16.50 & 2.17 & 1.260 & $05 / 19$ \\
\hline 1954 & 14.20 & $4 \cdot 36$ & 2.278 & $07 / 21$ \\
\hline 1955 & 23.00 & 2.22 & 4.200 & $03 / 06$ \\
\hline 1956 & 13.50 & 2.32 & 1.670 & $04 / 16$ \\
\hline 1957 & 35.70 & 3.25 & 3.600 & $01 / 29$ \\
\hline 1958 & 16.10 & 2.35 & 1.280 & $08 / 25$ \\
\hline 1959 & 8.70 & 1.10 & 1.180 & $04 / 12$ \\
\hline 1960 & 4.66 & 1.22 & 0.798 & $11 / 28$ \\
\hline 1961 & 8.90 & 0.74 & 1.460 & $02 / 25$ \\
\hline 1962 & 10.20 & 1.39 & 1.120 & $02 / 28$ \\
\hline 1963 & 28.30 & 2.66 & 4.570 & $03 / 12$ \\
\hline 1964 & 7.58 & 1.47 & 0.836 & $03 / 09$ \\
\hline 1965 & 16.30 & 2.78 & 1.510 & $03 / 26$ \\
\hline 1966 & 8.96 & 2.20 & 1.050 & $05 / 02$ \\
\hline 1967 & 20.70 & 2.04 & 4.600 & $03 / 07$ \\
\hline 1968 & 13.80 & 1.56 & 1.060 & $05 / 27$ \\
\hline 1969 & 2.23 & 0.78 & 0.308 & $01 / 21$ \\
\hline 1970 & 11.50 & 1.49 & 1.820 & $02 / 16$ \\
\hline 1971 & 13.50 & 2.75 & 1.480 & $05 / 07$ \\
\hline 1972 & 17.30 & 2.22 & 1.340 & $01 / 21$ \\
\hline 1973 & 18.70 & 2.64 & 2.510 & $03 / 17$ \\
\hline 1974 & 18.60 & 1.81 & 1.790 & $01 / 11$ \\
\hline 1975 & 18.20 & 2.11 & 1.450 & $03 / 14$ \\
\hline 1976 & 5.43 & 1.48 & 0.452 & $01 / 01$ \\
\hline 1977 & 54.50 & 4.66 & 5.140 & $04 / 04$ \\
\hline 1978 & 25.80 & 1.36 & 3.210 & $01 / 26$ \\
\hline 1979 & 13.80 & -- & 1.160 & $01 / 21$ \\
\hline
\end{tabular}




\section{APPENDIX C: DATA SET FOR TUG FORK NEAR KERMIT, WEST VIRGINIA}

The years are water years. $Q$ is the annual-flood peak at the Kermit gage, $R$ is the associated maximum 2-day rainfall at Davella, Ky., $\mathrm{P}$ is the associated flood peak at the Panther Creek near Panther, W. Va., gage. KCFS is thousands of cubic feet per second.

\begin{tabular}{|c|c|c|c|c|}
\hline & $Q$ & $\mathrm{R}$ & $\mathrm{P}$ & \\
\hline & in & in & in & \\
\hline year & KCFS & inches & KCFS & date \\
\hline 1940 & 7.37 & 1.58 & -- & $04 / 20$ \\
\hline 1941 & 8.72 & 0.49 & -- & $03 / 12$ \\
\hline 1942 & 12.80 & 2.26 & -- & $08 / 05$ \\
\hline 1943 & 27.00 & 2.07 & -- & $12 / 30$ \\
\hline 1944 & 17.30 & 2.16 & -- & $04 / 12$ \\
\hline 1945 & 24.00 & 1.71 & -- & $03 / 06$ \\
\hline 1946 & 31.40 & 2.55 & -- & $01 / 08$ \\
\hline 1947 & 12.20 & 1.21 & 0.576 & $01 / 21$ \\
\hline 1948 & 31.10 & 1.80 & 1.700 & $02 / 14$ \\
\hline 1949 & 14.50 & 1.28 & 0.948 & $03 / 19$ \\
\hline 1950 & 31.80 & 2.75 & 1.350 & $02 / 02$ \\
\hline 1951 & 27.20 & 3.72 & 0.906 & $02 / 01$ \\
\hline 1952 & 26.50 & 3.25 & 1.170 & $03 / 23$ \\
\hline 1953 & 19.50 & 1.53 & 1.260 & $05 / 20$ \\
\hline 1954 & 14.40 & 1.10 & -- & $07 / 22$ \\
\hline 1955 & 44.60 & 2.37 & 3.570 & $02 / 28$ \\
\hline 1956 & 30.00 & 2.74 & 1.670 & $04 / 15$ \\
\hline 1957 & 61.30 & 2.39 & 3.600 & $01 / 30$ \\
\hline 1958 & 46.80 & 1.91 & 1.350 & $05 / 07$ \\
\hline 1959 & 14.60 & 1.26 & 1.180 & $04 / 13$ \\
\hline 1960 & 8.90 & -- & 0.798 & $11 / 29$ \\
\hline 1961 & 17.00 & 1.01 & 1.460 & $02 / 26$ \\
\hline 1962 & 39.50 & 4.57 & 1.120 & $02 / 27$ \\
\hline 1963 & 69.60 & 2.57 & 4.570 & $03 / 13$ \\
\hline 1964 & 13.70 & 1.80 & 0.836 & $03 / 09$ \\
\hline 1965 & 28.20 & -- & 1.510 & $03 / 27$ \\
\hline 1966 & 19.00 & 1.69 & 1.050 & $05 / 02$ \\
\hline 1967 & 59.00 & 3.35 & 4.600 & $03 / 07$ \\
\hline 1968 & 19.60 & 1.37 & 1.060 & $05 / 28$ \\
\hline 1969 & 6.76 & 1.03 & 0.308 & $01 / 21$ \\
\hline 1970 & 32.20 & 3.72 & 1.390 & $12 / 31$ \\
\hline 1971 & 27.00 & -- & 1.480 & $05 / 08$ \\
\hline 1972 & 46.80 & -- & 1.510 & $02 / 26$ \\
\hline 1973 & 34.60 & 1.35 & 2.510 & $03 / 17$ \\
\hline 1974 & 53.00 & 2.86 & 1.790 & $01 / 11$ \\
\hline 1975 & 31.20 & 2.60 & 1.450 & $03 / 15$ \\
\hline 1976 & 11.20 & -- & 0.452 & $01 / 01$ \\
\hline 1977 & 104.00 & 2.57 & 5.140 & $04 / 06$ \\
\hline 1978 & 44.30 & - & 3.210 & $01 / 27$ \\
\hline 1979 & 39.10 & -- & 1.180 & $12 / 09$ \\
\hline
\end{tabular}




\section{APPENDIX D: AUGMENTED DATA SET FOR TUG FORK NEAR KERMIT, WEST VIRGINIA}

The years are water years. $Q$ is the annual-flood peak at the Kermit gage, $R$ is the associated maximum 2-day rainfall at Davella, Ky. If the Davella value is missing, the Pikeville, Ky., rainfall is used. $\mathrm{P}$ is the associated flood peak at the Panther Creek near Panther, W. Va., gage. If it is missing, it is estimated from the regression relation of 2-day maximum precipitation at Hurley, W. Va., and Panther Creek peak discharge. KCFS is thousands of cubic feet per second.

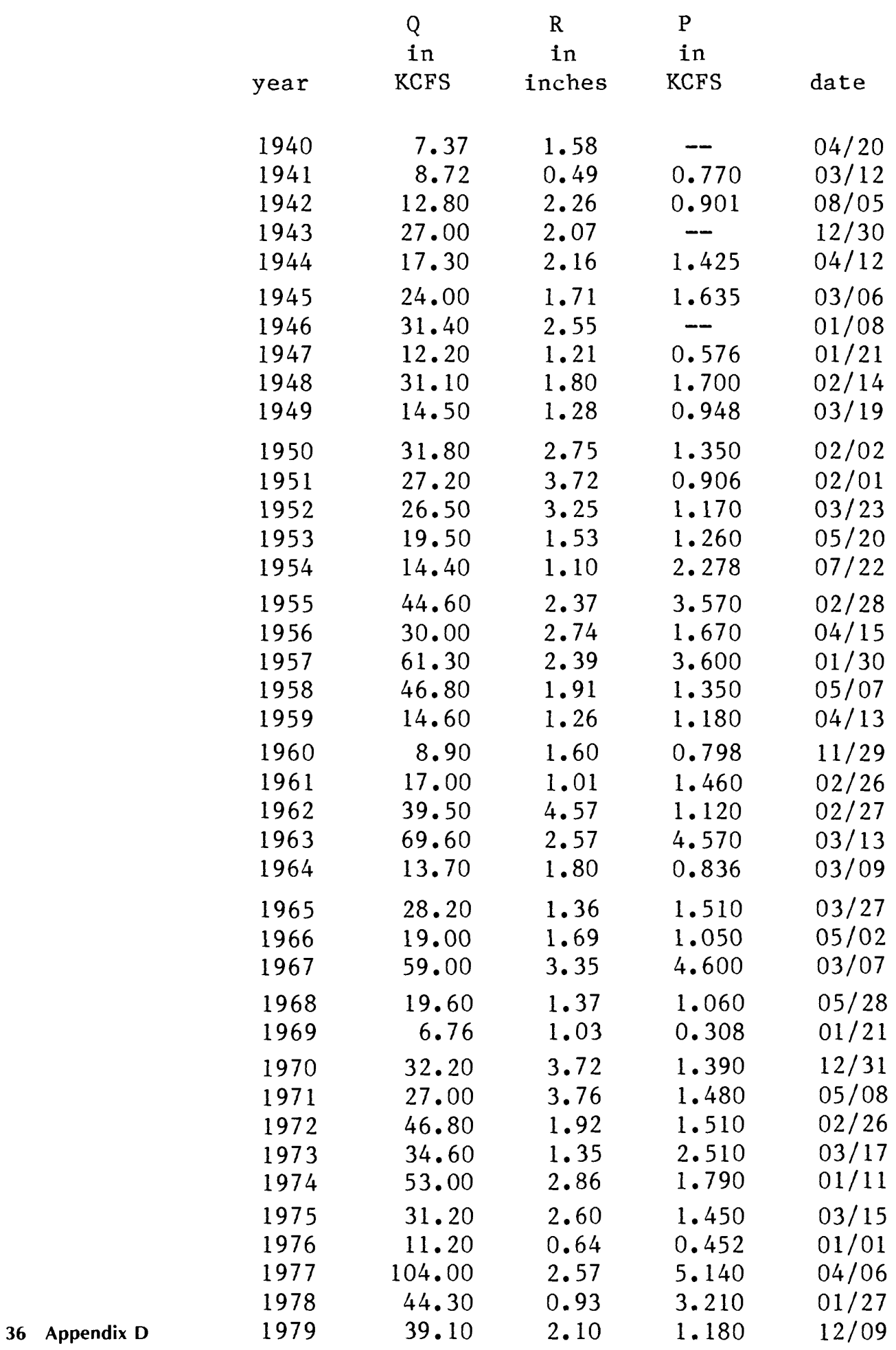




\section{APPENDIX E: DATA SET FOR PANTHER CREEK NEAR PANTHER, WEST VIRGINIA}

The years are water years. $Q$ is the annual-flood peak at the Panther Creek gage, $R$ is the associated maximum 2-day rainfall at Hurley, Va., rain gage. KCFS is thousands of cubic feet per second.

$\begin{array}{lccc} & \text { P } & \mathrm{R} & \\ \text { year } & \begin{array}{c}\text { in } \\ \text { KCFS }\end{array} & \begin{array}{c}\text { in } \\ \text { inches }\end{array} & \text { date } \\ & & & \\ 1947 & 0.576 & -- & 01 / 20 \\ 1948 & 1.700 & 1.91 & 02 / 13 \\ 1949 & 0.948 & 1.40 & 03 / 18 \\ & & & \\ 1950 & 1.350 & 2.32 & 02 / 02 \\ 1951 & 0.906 & 1.17 & 02 / 01 \\ 1952 & 1.260 & 1.85 & 04 / 28 \\ 1953 & 1.260 & 1.73 & 05 / 19 \\ 1954 & 0.492 & 1.43 & 01 / 22 \\ & & & \\ 1955 & 4.200 & 2.60 & 03 / 06 \\ 1956 & 1.670 & 2.65 & 04 / 15 \\ 1957 & 3.600 & 3.25 & 01 / 29 \\ 1958 & 1.350 & -- & 05 / 07 \\ 1959 & 1.660 & 1.73 & 01 / 22 \\ 1960 & 0.798 & -- & 11 / 28 \\ 1961 & 1.810 & 1.61 & 05 / 12 \\ 1962 & 1.120 & 1.55 & 02 / 28 \\ 1963 & 4.570 & -- & 03 / 12 \\ 1964 & 0.836 & -- & 03 / 08 \\ 1965 & 1.890 & 2.42 & 01 / 10 \\ 1966 & 1.920 & 2.45 & 09 / 27 \\ 1967 & 4.600 & 3.62 & 03 / 07 \\ 1968 & 1.060 & 2.30 & 05 / 27 \\ 1969 & 0.308 & 1.30 & 01 / 20 \\ 1970 & 1.820 & -- & 02 / 15 \\ 1971 & 1.480 & 1.65 & 05 / 06 \\ 1972 & 1.510 & 2.52 & 02 / 24 \\ 1973 & 2.510 & 2.79 & 03 / 16 \\ 1974 & 1.790 & -- & 01 / 11 \\ 1975 & 2.130 & 1.40 & 04 / 25 \\ 1976 & 0.452 & -- & 12 / 31 \\ 1977 & 5.140 & 4.60 & 04 / 04 \\ 1978 & 3.210 & 2.30 & 01 / 26 \\ 1979 & 2.630 & -- & 06 / 22\end{array}$

